IZA DP No. 4207

Brain Drain in Globalization:

A General Equilibrium Analysis from the Sending Countries' Perspective

Luca Marchiori

I-Ling Shen

Frédéric Docquier

June 2009 


\title{
Brain Drain in Globalization: A General Equilibrium Analysis from the Sending Countries' Perspective
}

\author{
Luca Marchiori \\ Catholic University of Louvain \\ and University of Luxembourg \\ I-Ling Shen \\ Catholic University of Louvain, \\ University of Geneva and IZA \\ Frédéric Docquier \\ Catholic University of Louvain, \\ Belgian National Fund of Scientific Research and IZA
}

\author{
Discussion Paper No. 4207 \\ June 2009
}

\author{
IZA \\ P.O. Box 7240 \\ 53072 Bonn \\ Germany \\ Phone: $+49-228-3894-0$ \\ Fax: +49-228-3894-180 \\ E-mail: iza@iza.org
}

\begin{abstract}
Any opinions expressed here are those of the author(s) and not those of IZA. Research published in this series may include views on policy, but the institute itself takes no institutional policy positions.

The Institute for the Study of Labor (IZA) in Bonn is a local and virtual international research center and a place of communication between science, politics and business. IZA is an independent nonprofit organization supported by Deutsche Post Foundation. The center is associated with the University of Bonn and offers a stimulating research environment through its international network, workshops and conferences, data service, project support, research visits and doctoral program. IZA engages in (i) original and internationally competitive research in all fields of labor economics, (ii) development of policy concepts, and (iii) dissemination of research results and concepts to the interested public.
\end{abstract}

IZA Discussion Papers often represent preliminary work and are circulated to encourage discussion. Citation of such a paper should account for its provisional character. A revised version may be available directly from the author. 


\section{ABSTRACT \\ Brain Drain in Globalization: A General Equilibrium Analysis from the Sending Countries' Perspective}

The paper assesses the global effects of brain drain on developing economies and quantifies the relative sizes of various static and dynamic impacts. By constructing a unified generic framework characterized by overlapping-generations dynamics and calibrated to real data, this study incorporates many direct impacts of brain drain whose interactions, along with other indirect effects, are endogenously and dynamically generated. Our findings suggest that the short-run impact of brain drain on resident human capital is extremely crucial, as it does not only determine the number of skilled workers available to domestic production, but it also affects the sending economy's capacity to innovate or to adopt modern technologies. The latter impact plays an important role particularly in a globalized economy where capital investments are made in places with higher production efficiencies ceteris paribus. Hence, in spite of several empirically documented positive feedback effects, those countries with high skilled emigration rates are the most candid victims to brain drain since they are least likely to benefit from the "brain gain" effect, and thus suffering from declines of their resident human capital.

JEL Classification: F22, J24, O15

Keywords: brain drain, capital flow, development, human capital, remittances

Corresponding author:

I-Ling Shen

Department of Econometrics

University of Geneva

Uni Mail

40 Bd du Pont d'Arve

$\mathrm{CH}-1211$ Geneva 4

Switzerland

E-mail: i-ling.shen@unige.ch 


\section{Introduction}

Is brain drain a curse or a boon for the sending countries? In the survey by Commander et al. (2004), while different forces at work are discussed and several possible positive and negative effects of skilled emigration are reviewed, they conclude by suggesting that "much more research is needed to pin down the relevant magnitudes." In order to study the global effects of brain drain on developing economies and to quantify the relative sizes of various static and dynamic impacts, a generic framework is certainly required, which is capable of incorporating the main mechanisms identified in the existing literature. With this aim, we develop a ten-region general equilibrium model characterized by overlapping-generations (OLG) dynamics and calibrated with real data. We assess the impacts of skill outflow using three economic indicators: Gross Domestic Product (GDP) per capita, Gross National Income (GNI) per capita, and the skilled-to-less-skilled income inequality. In such a framework, not only can we juxtapose the direct impacts of brain drain, but their interactions and other indirect effects are also endogenously and dynamically generated. This is a very important step forward, as skilled emigration is not an isolated incident, but it ripples through the entire global economic system.

In the process of economic globalization, international movement of production factors is an essential component that stimulates further integration of the world economy. On the one hand, financial liberalization and the practice of international arbitrage contribute to large cross-border flows of capital. While the amount of Foreign Direct Investment (FDI) at the world level has increased from 13,346 millions in 1970 to 1,833,324 millions in 2007 (measured in US $\$$ at current prices), the rise in FDI per capita is far more remarkable in the developed economies alias "North", than in the developing economies alias "South" (see Figure 1). This North-South disparity reflects largely the wide gaps in terms of total factor productivity, and not insignificantly, the higher risks involved in investing in many developing countries. ${ }^{1}$

Similarly, international wage gaps are the most important pull factor that lures economic migrants from the developing to the developed economies (Clemens and Pritchett, 2008; Grogger and Hanson, 2008). The immigration rate in high-income countries has tripled since 1960 and doubled since 1985.

\footnotetext{
${ }^{1}$ See, for example, the Country Risk Classification produced by the Organisation for Economic Co-operation and Development (OECD).
} 
Moreover, Docquier et al. (2009) document that, in OECD countries, two thirds of the increase in immigration stocks during the 1990s are accounted for by the South-to-North movement. When skill heterogeneity is taken into account, it is found that the number of highly educated immigrants has increased by 70 percent, whereas the corresponding figure for immigrants with lower educational attainments is a dwarfed 30 percent. Although this difference does not necessarily imply an increasing trend of brain drain, ${ }^{2}$ stylized facts show that there does exist strong positive selection of emigrants, especially in the lower income countries (see Figure 2). In many developing countries, brain drain rates are well above 40 percent, particularly for subSaharan African countries, Central American countries, and small states. ${ }^{3}$

This positive selection may originate from either self-selection into emigration or from the destination country's immigration policy. As shown by Grogger and Hanson (2008), the larger international wage differences for skilled than for less-skilled workers are consistent with positive self-selection. Moreover, in poorer countries, this pattern can be further reinforced when credit constraints are binding and less-skilled potential migrants cannot afford migration costs (Chiquiar and Hanson, 2005). On the other hand, admission criterion adopted by major labor-receiving countries have grown progressively skilled-biased. ${ }^{4}$ This raises the probability to migrate for highlyeducated young workers, while restrictions imposed on immigration of the less-skilled are generally not relaxed, if not increased. Despite that trade barriers have been greatly reduced and capital markets liberalized, the national barriers to immigration remain substantial; consequently, notwithstanding the rise in immigration rates, people flows in globalization are much less

\footnotetext{
${ }^{2}$ In fact, Defoort (2008) demonstrates that brain drain rates, measured as the emigration rates of the skilled natives, were relatively stable over time. This may be due to the general rise in educational attainments in developing countries; thus, increases in the number of skilled emigrants are accompanied by a more educated population at origin.

${ }^{3}$ The skilled emigration rate exceeds 70 percent in a dozen countries.

${ }^{4}$ Put aside the traditional emphasis on family reunion, immigration policy-setting has grown more skilled-biased in the major immigrant receiving countries. In 1967, Canada adopts the point system that favors highly educated and highly skilled young individuals. Australia followed suit in 1989, then New Zealand in 1991. In 2006, a detailed plan was presented in the British Parliament on how to implement a points-based immigration system. In the United States, the immigration reform bill of 2007, although failed, also includes a similarly merit-based system. In the same year, the European Commission announced her "Blue Card" scheme in the hope of luring more skilled migrants.
} 
in extent when compared to other international flows of factors and goods (Freeman, 2006).

Although the debate over open/close border to immigration have so far remained mainly in the political and philosophical domains, ${ }^{5}$ the economic literature of brain drain has already gained major attention back in the 1970s. This can be attributed to the pioneering works of Bhagwati (1972, 1976a,b), where the well-known "Bhagwati Tax" was proposed and aimed to compensate for the loss incurred by skill outflow in the developing countries. However, in Bhagwati and Hamada (1974, 1975), this loss is predicted in a partial equilibrium framework characterized by wage rigidity, unemployment, and fiscal costs, with brain drain worsening wage distortions and accentuating fiscal externality, yet generating few potentially counteracting effects. Moreover, as skilled labor serves as a pivotal engine of growth, modern theories of brain drain based on endogenous growth models also predict pessimistic outcomes, due to externalities related to human capital formation (Miyagiwa, 1991; Haque and Kim, 1995; Wong and Yip, 1999). On top of these theoretical adverse effects, emigration in general implies loss of working-age population in the sending countries. This may pose as a serious threat to those developing economies with high emigration rates as well as a substantial degree of population aging, most notably the Eastern Europe countries. ${ }^{6}$

Recent developments in the migration literature, however, have identified a series of positive feedback effects. Starting from Stark et al. (1997, 1998), it is demonstrated that increased migration prospects for the skilled could stimulate more human capital formation, thanks to higher expected returns to education; thus, in countries with low skilled-emigration rates, their expost human capital stocks increase as a result. ${ }^{7}$ Furthermore, diaspora at the destination countries may reduce information-related investment risks and is shown to spur FDI at the origin countries (Kugler and Rapoport, 2007;

\footnotetext{
${ }^{5}$ There are some economic studies discussing the issue of migration barriers and their welfare costs, see for example, Freeman (2006) and Clemens and Pritchett (2008).

${ }^{6}$ In less developed regions, the average share of population aged 65 or over is expected to rise from $5.0 \%$ in 2000 to $14.6 \%$ in 2050; however, when Eastern Europe is considered alone, the rise goes from $12.9 \%$ in 2000 to $25.4 \%$ in 2050 (see the United Nations' (U.N.) World Population Prospects: The 2008 Revision).

${ }^{7}$ See Mountford (1997), Vidal (1998), Stark and Wang (2002), Stark (2004), and the empirical evidence in Beine et al. (2001, 2008a).
} 
Docquier and Lodigiani, 2009). Through immigrants' ties with their home countries, diaspora may also lower transaction costs, and empirical evidence suggests that it encourages bilateral trade flows (Gould, 1994; Head and Ries, 1998). While the aforementioned network externalities are not specific to more educated migrants, skilled diaspora nevertheless plays a unique role in promoting international technology diffusion, which raises the total factor productivity in immigrants' home countries (Kerr, 2008; Lodigiani, 2008). ${ }^{8}$ Arguably, the list of potentially positive effects of diaspora may also include transferring of norms, which could alter fertility behavior (Beine et al., 2008b) or bring about institutional reforms (Spilimbergo, 2009), ${ }^{9}$ and thus indirectly enhancing economic development at the origin.

From the above, it is apparent that international flows of factors and goods/services are not independent of one another, as already demonstrated in the traditional trade theory. However, their inter-dependencies are not unambiguous. For example, static trade models predict that, a change in factor endowment differential, due to an exogenous reallocation of labor to the North from the South, must raise returns to capital at the destination and induce capital outflow from the origin. In the meantime, the aforementioned evidence on network externalities indicate that emigration and FDI inflows may well act as complements, especially from a dynamic perspective; ${ }^{10}$ moreover, technology diffusion can also augment the marginal productivity of capital in the South and attract more capital investments. Last but not

\footnotetext{
${ }^{8}$ Kerr (2008) finds that, how technology diffusion spurs output growth differs with the home country's development level. In less developed countries, this positive effect is more likely to transmit through the reallocation of labor from the agricultural to the manufacturing sector. However, this paper does not distinguish different sectors due to the already complex setting of our dynamic model. For the same reason, we do not take into account another possible complementary link between skilled emigration and FDI inflows put forward by Ivlevs and de Melo (2008). They suggest that, when the non-trading sector is more skill intensive than the production of traded goods, brain drain raises the price of non-traded goods and leads to capital inflow to this very sector.

${ }^{9}$ Notice that Spilimbergo (2009) does not exactly study the diaspora effect on institutional reforms. Alternatively but relatedly, he studies whether foreign educated individuals play a role in promoting democracy in their home country, and he finds a positive impact if foreign education is acquired in democratic countries.

${ }^{10}$ For instance, Kugler and Rapoport (2007) observes dynamic complementarity but contemporaneous substitutability between emigration and FDI inflows. While the former suggests the existence of network externalities, the latter is consistent with factor reallocation in the trade models.
} 
the least, the officially recorded amount of remittances has been increasing at a fast rate, ${ }^{11}$ suggesting yet another complementary and important link between labor emigration and capital inflows (Walmsley and Winters, 2005), and it further promotes economic growth in the relatively capital-scarce developing countries, particularly those with less developed financial systems (Giuliano and Ruiz-Arranz, 2008).

In order to assess the global effects of South-to-North brain drain on the sending economies, this paper utilizes a calibrated OLG model, which divides the world into three developed and seven developing regions. In each decade from 2010-20 to 2050-60, we increase by 20 percent the forecast flow of skilled migrants from every developing region to each developed region. Increases in skilled immigration in the North may be owed to either an enlarging international gap of skilled wage, or to an increasingly skilled-biased immigration policy in response to aging, occupational shortage, and so forth. However, in order to maintain tractability in the already complex setting, these decennial 20-percent increases are treated as exogenous shocks. Moreover, whereas our generic framework is capable of incorporating many of the potential effects of brain drain reported in the existing literature, some of them are not included due to compatibility issues (e.g., increasing bilateral trade flows, transferring of norms, etc.).

Despite the constraints, the greatest advantage of our unified generic framework is that it allows for the interactions between different forces at work. This is especially important in a globalized economy, where international flows of people are often accompanied by international flows of other factors, as mentioned above. Moreover, the OLG framework makes it feasible to take into account the impacts of brain drain through the age structure, and it also allows for dynamic effects via asset accumulation. ${ }^{12}$ In the simulations, it is observed that the demographic shock of additional brain drain gener-

\footnotetext{
${ }^{11}$ In 2005, the officially recorded amount of remittances to developing countries exceeded total development aid and equalized total FDI. It continued to grow at a double-digit rate during 2005-2007, but slowed down in 2008, likely due to the global financial crisis (see the World Bank's Global Economic Prospects 2009).

${ }^{12}$ Docquier and Rapoport (2009) studies the overall costs and benefits of brain drain on the per country basis. However, in their partial equilibrium setting where all effects occur through the production parameters except labor endowment, all direct impacts of brain drain are simulated outside the production equation. Hence, their study incorporates neither the changes in international capital flows, nor the impacts on the demographic structure and the amounts of consumption/savings.
} 
ates multiple positive and negative impacts through four channels. First, demographic changes in the age structure result in less working-age population to support the retirees. Second, the incentive effect on human capital formation contribute to "brain gain" in regions where skilled emigration is less prevalent. Third, technological progress is accelerated in technologically less-advanced regions, where the skilled diaspora plays an important role in facilitating technology diffusion; on the other hand, however, the loss of skilled human capital also breeds dynamic impacts that slow down the catching-up of technology. Forth, an enlarged diaspora helps to reduce information-related investment risks at origin, and thus attracting more FDI inflows.

Our findings suggest that the winners and losers of brain drain can be distinguished by the short-run impacts on their resident human capital, which in turn affects technological progress via a regions' capacity to innovate or to adopt modern technologies. Therefore, the loser regions are characterized by high skilled emigration rates, which make them less likely to benefit from the "brain gain" effect, and/or by relatively more advanced technology level, with which technology diffusion generates less benefits. Most importantly, it is found that the reason why the impacts working through the technology mechanism generates a large impact is greatly due to international capital mobility, as production technology defines production efficiency, which is one of the most important determinants of returns to physical capital. In other words, the benefits and the harms of brain drain can be amplified when it takes place in globalization.

The rest of the paper is organized as follows. Section 2 presents the calibrated OLG model and describes the calibration methods. In Section 3, the simulated results are summarized and followed by a detailed analysis, where the dominant channels are identified through which brain drain impacts the developing economies, and the conditions are explained under which each channel generates positive or negative impacts. Finally, Section 4 concludes.

\section{Model}

We introduce international migration with skill heterogeneity into a general equilibrium model with overlapping generations of individuals. The model economy is composed of ten regions, similarly to the INGENUE model 
built by Aglietta et al. (2005). ${ }^{13}$ We distinguish three developed regions, or the North, which includes

- North America (NAM),

- Japan (JAP), and

- other high-income advanced countries (ADV).

Seven developing regions, or the South, are grouped as follows:

- Eastern Europe (EAS),

- Middle East and Northern Africa (MEN),

- Latin America and the Caribbean (LAC),

- Sub-Saharan Africa (SSA),

- the Former Soviet Union (RUS),

- the Chinese world (CHI), and

- the Indian world and Pacific Islands (IND).

Table 1 provides a glimpse at the regional characteristics of the South in 2000, which includes a region's demographic share of the population aged 25 or over among all developing regions (Demog), then for each region itself, the proportion of skilled in the resident population (Skill), ${ }^{14}$ the average emigration rate towards the OECD countries (Aemig), the skilled emigration rate (Semig), the less-skilled emigration rate (Lemig), and the ratio of remittances to GDP (Rem/Y). ${ }^{15}$ Each region exhibits a strong pattern of positive selection into emigration, with the skilled emigration rate exceeds, in some cases by more than 30 times, the less-skilled emigration rate. Moreover, in certain regions such as SSA, the loss of human capital seems particularly

\footnotetext{
${ }^{13}$ The detailed list of countries by region can be found in Table A.1.

${ }^{14}$ Due to data availability, the skilled is defined as those with post-secondary degrees.

${ }^{15}$ Regarding remittances, the amounts presented in Table 1 are taken from the IMF database and are usually seen as underestimating the reality since many transfers are channeled through the informal sector. It is a priori difficult to estimate the regionspecific bias. Thus, we will only consider the official IMF numbers in our analysis.
} 
Table 1: Regional characteristics in 2000 (in \%)

\begin{tabular}{lrrrrrr}
\hline \hline Region & Demog & Skill & Aemig & Semig & Lemig & Rem/Y \\
\hline EAS & 3.9 & 12.4 & 6.6 & 11.8 & 5.3 & 1.3 \\
MEN & 6.2 & 8.5 & 3.5 & 8.5 & 2.8 & 2.8 \\
LAC & 10.2 & 11.8 & 4.3 & 11.0 & 3.1 & 2.0 \\
SSA & 9.7 & 2.8 & 0.8 & 12.9 & 0.4 & 2.6 \\
RUS & 3.0 & 18.9 & 2.0 & 2.6 & 1.8 & 0.6 \\
CHI & 36.6 & 3.8 & 0.5 & 7.3 & 0.2 & 0.8 \\
IND & 30.3 & 4.5 & 0.4 & 5.2 & 0.2 & 1.8 \\
\hline Total & 100.0 & & & & &
\end{tabular}

Data source: Docquier and Marfouk (2006) and the International Monetary Fund (IMF).

alarming given its low proportion of skilled population. Finally, the ratio of remittances to GDP is small but non-negligible for all regions.

Our OLG model is dynamically calibrated so that it matches to a very high degree the regional structures and the inter-regional disparities over the period 1950-2000. It consists of two main blocks with a recursive structure. To account for the empirical elasticities estimated in the literature, we build an "upstream block", calibrated outside the core of the model using data and empirical studies. This block predicts the evolution of demographic variables, human capital, and the magnitude of diaspora externalities. Then, these predictions are incorporated into a "micro-founded block" within a general equilibrium framework. This block generates predictions for the world output, prices, remittances, asset accumulation, the geographical allocation of assets, the international flows of capital income and other endogenous variables. In order to assess the global effects of brain drain on the developing economies, demographic shocks of additional skilled emigration are introduced during the period 2010-2050, and the analysis will focus on the transitional path during the period $2000-2100 .^{16}$

In the ensuing sections, we will describe the structure of the two main building blocks and specify the demographic shock in the context of the model economy. For clarity of the exposition, we will begin with the micro-founded block.

\footnotetext{
${ }^{16}$ The model economy starts from an initial steady-state in 1870, and after demographic shocks are introduced, the new steady state is reached in 2200 .
} 


\subsection{The micro-founded block}

Each region has three types of agents: households, the firm, and the government. Before depicting the behavior of each type of agents, it is essential to discuss the demographic composition.

$\odot$ Demography: At each period, there are eight overlapping generations denoted by $a$, with $a=0$ standing for the age class $15-24, a=1$ for $25-34$, and so on, up to $a=7$ for 85-94. Individuals have uncertain longevities, meaning that they may die at the end of every period. Each individual of the same generation faces an identical cumulative survival probability, which decreases with age. Hence, the size of each generation $\left(N_{a, t+a}\right)$ declines deterministically over time:

$$
N_{a, t+a}=P_{a, t+a} N_{0, t} \quad a=\{0,1, \ldots, 7\},
$$

where $P_{a, t+a} \in[0,1]$ is the exogenous fraction of generation $a$ born at period $t$ alive at period $t+a$, with $P_{0, t}=1$.

The size of the young generation $(a=0)$ increases over time at an exogenous growth rate:

$$
N_{0, t}=m_{t-1} N_{0, t-1}
$$

where $N_{0, t}$ measures the initial size of the young generation, and $m_{t-1}$ is one plus the population growth rate, which includes both fertility and migration. It is assumed that migration takes place at the first period of life (i.e., $a=0$ ) and is permanent. This is a reasonable assumption since we focus on the South-to-North migration of the skilled, who are likely to migrate, along with their family members, on a more permanent basis. ${ }^{17}$

Individuals belonging to the same generation are heterogeneous in terms of their skills. They are either skilled (denoted by $s$ ) or less-skilled (denoted by $l$ ). It is assumed that an individual obtains post-secondary schooling and becomes skilled before reaching age $25 .{ }^{18}$ Let $\phi_{t}$ stand for the proportion of

\footnotetext{
${ }^{17}$ This assumption is made also out of consideration for analytical tractability, so that migrants and natives living in the same region have identical asset accumulations.

${ }^{18}$ Our perception of skilled versus less-skilled labor is similar to the one described in Cervellati and Sunde (2005). Each individual is endowed with one unit of less-skilled labor; however, it is transformed into a skilled unit upon the completion of post-secondary education, when one has acquired the ability of abstract reasoning. This specification is consistent with empirical evidence showing perfect substitutability between high school graduates and dropouts (Ottaviano and Peri, 2008; Card, 2009), and it also explains why
} 
the skilled among the young generation born at period $t$. The populations of the skilled and the less-skilled youth are then given respectively by:

$$
\begin{aligned}
& N_{0, t}^{s}=\phi_{t} N_{0, t} \\
& N_{0, t}^{l}=\left(1-\phi_{t}\right) N_{0, t}
\end{aligned}, \quad \phi_{t} \in[0,1]
$$

An exogenous profile of participation in the labor market is assumed per age and skill group (denoted by $\lambda_{a, t}^{j}$ ). Hence, labor supply of a type $j$ individual at period $t$ is given by

$$
L_{t}^{j}=\sum_{a=0}^{7} \lambda_{a, t}^{j} N_{a, t}^{j} \quad j=\{s, l\} .
$$

Specifically, full participation is assumed except for the following three groups. First, the skilled youth spend a fraction of their time in obtaining education and do not fully participate in the labor market (i.e., $\left.\lambda_{0, t}^{s} \in\right] 0,1[$ ). Second, part of the population aged 55-64 are retired (i.e., $\left.\lambda_{4, t}^{j} \in\right] 0,1[, j=\{s, l\})$. Lastly, all individuals aged above 65 are retired (i.e., $\left.\lambda_{a, t}^{j}=0, \forall a>4, j=\{s, l\}\right)$.

$\odot$ Households: Each non-migrant individual derives utility from her lifetime consumption. The expected utility function is assumed to be time-separable and logarithmic:

$$
E\left(U_{t}^{j}\right)=\sum_{a=0}^{7} P_{a, t+a} \ln \left(c_{a, t+a}^{j}\right) \quad j=\{s, l\},
$$

where $c_{a, t+a}^{j} \geq 0$ denotes the amount of goods consumed by a non-migrant individual of generation $a$ at period $t+a$. The price of goods is normalized to unity; therefore, $c_{a, t+a}^{j}$ also equals to her total expenditures of the same period.

However, migrants, i.e., those born in the South and living in the North, are assumed to derive utility from a combination of goods consumption $\left(c^{M, j}\right)$ and remittances $\left(R M^{M, j}\right)$ :

$$
c_{a, t+a}^{j}=\left(c_{a, t+a}^{M, j}\right)^{1-\gamma^{j}}\left(R M_{a, t+a}^{M, j}\right)^{\gamma^{j}} \quad j=\{s, l\},
$$

the skilled diaspora is unique in facilitating technology diffusion (see Section 1). 
where $\gamma^{j} \in[0,1]$ is a time-invariant and age-invariant propensity to remit. It determines the share of total expenditures that a migrant of skill type $j$ sends home as remittances. This exogenous parameter is region-specific and calibrated using the IMF recorded remittance receipts in $2003 .{ }^{19}$

Following de la Croix and Docquier (2007), we postulate the existence of an insurance mechanism à la Arrow-Debreu. Each time after an individual dies, her assets are equally distributed among individuals belonging to the same generation living in the same region. Individuals thus maximize their expected utility subject to a budget constraint requiring equality between the discounted expected value of expenditures and the discounted expected value of income, which consists of net labor income, pension benefits, other welfare transfers and/or net remittances. The household optimization problem determines the age profiles for consumption, remittances, savings, and asset accumulation.

$\odot$ Firm: At each period and in each region, a representative and profitmaximizing firm uses efficient labor $\left(L_{t}\right)$ and physical capital $\left(K_{t}\right)$ to produce a composite good $\left(Y_{t}\right){ }^{20}$ A Cobb-Douglas production function is assumed with constant returns to scale,

$$
Y_{t}=K_{t}^{\alpha}\left(A_{t} L_{t}\right)^{1-\alpha} \quad \alpha \in[0,1]
$$

where $A_{t}>0$ is an exogenous parameter representing the Harrod neutral technological progress. $\alpha$ measures capital intensity of production, and under the assumption of perfect competition with unity goods price, it also stands for the share of gross capital returns in the total domestic product. It is as-

\footnotetext{
${ }^{19}$ Remittances are modelled in this way for the same reason explained in Footnote 17. The age-invariance of the propensity to remit comes from our implicit assumption that there is no remittances decay, due to scant empirical evidence.

${ }^{20}$ With our modeling of the production sector, we implicitly assumes that every region produces homogeneous goods. They are traded freely, and the international goods market is cleared by Walras' law. Hence, a region either imports or exports and no bilateral trade exists. Given our focus on factor flows and their (real) prices, we choose this parsimonious modeling of international trade. Furthermore, if the Hecksher-Ohlin type of assumptions are satisfied, free trade would have led to factor price equalization even without factor mobility. However, these assumption are not satisfied in our setting. As discussed later, the ex-post gross returns to capital do not equalize because of region-specific risk premiums, while cross-country differences in technology, along with capital endowment differentials, contribute to international wage gaps.
} 
sumed that physical capital is mobile across regions; thus, the marginal productivity of capital is equal to the international interest rates $r_{t}^{*}$ augmented by the region-specific risk premium $\left(\pi_{t} \geq 0\right)$, which reflects investment risks:

$$
r_{t}^{*}\left(1+\pi_{t}\right)=\alpha\left(\frac{A_{t} L_{t}}{K_{t}}\right)^{1-\alpha}
$$

The total efficient labor is a combination of skilled $\left(L_{t}^{s}\right)$ and of less-skilled labor $\left(L_{t}^{l}\right)$ according to a constant-elasticity-of-substitution (CES) function:

$$
L_{t}=\left[v_{t}\left(L_{t}^{s}\right)^{\sigma}+\left(1-v_{t}\right)\left(L_{t}^{l}\right)^{\sigma}\right]^{1 / \sigma} \quad \sigma<1,
$$

where $v_{t}$ is an exogenous skill-biased technical change, and $\sigma \equiv 1-1 / \epsilon$, with $\epsilon$ denoting the elasticity of substitution between skilled and less-skilled labor. The skilled and less-skilled wage rates (respectively $w_{t}^{s}$ and $w_{t}^{l}$ ) are determined by their respective marginal productivities. The skill wage premium is therefore

$$
\frac{w_{t}^{s}}{w_{t}^{l}}=\frac{v_{t}}{1-v_{t}} \cdot\left(\frac{L_{t}^{s}}{L_{t}^{l}}\right)^{\sigma-1}
$$

$\odot$ Government: The government levies taxes on labor earnings and on consumption expenditures in order to finance general public consumption, pension benefits and other welfare transfers. The government also issues bonds and pays interests on public debt. In every developing region, the government receives foreign development aid, and the amount of which is calibrated with the OECD data of official development assistance. The government budget constraint is satisfied at each period by adjusting the wage tax rate.

The pension system is modeled in a way as to allow for different pension systems in each region. The regional pension systems are partly Bismarckian (benefits proportional to wages) and partly Beveridgian (lump-sum benefits). We use a region-specific parameter capturing the wage-related fraction of benefit. Public debt is computed from the World Bank's World Development Index (WDI), with the exceptions being the public debt in ADV and in JAP, which are obtained from the OECD data on Gross Financial Liabilities.

$\odot$ Equilibrium: A competitive equilibrium of the open economy is characterized by (i) households' and the firm's first order conditions, (ii) marketclearing conditions on the goods and labor markets, (iii) budget balance for each regional government, (iv) the equality between the aggregate quantity 
of world assets and the quantity of the world capital stock plus the sum of public debts of all regions, and finally (v) the international arbitrage condition of returns to capital. The equilibrium on the goods market is achieved by Walras' law.

\subsection{The upstream block}

In the upstream block, data are used to calibrate the baseline parameters of the model economy. Moreover, elasticities estimated in empirical studies are incorporated to predict the evolution of demographic variables, the effect of migration on human capital accumulation, and the magnitudes of diaspora externalities.

$\odot$ Demographic parameters: The survival probability $P_{a, t+a}$ in Eq. (1) and the population growth rate $m_{t}$ in Eq. (2) are calibrated for the period 19502050, using the U.N. World Population Prospects, the 2000 Revision. In order to compute the skilled share of every generation, we use the Barro-Lee Dataset (2001), which provides yearly by-country data on the educational attainment of individuals aged 25-74 for the period $1950-2000 .{ }^{21}$ It is assumed that the skilled share of the young generation, $\phi_{t}$ in Eq. (3), remains the same from year 2000 onwards.

Our definition of migrants refers to foreign-born individuals living in the destination regions. In order to calibrate the South-to-North migration stocks and flows at the baseline, we explicitly track migrants from the seven developing to the three developed regions. ${ }^{22}$ In other words, Our calibration

\footnotetext{
${ }^{21}$ We firstly aggregate this data set by region and then partition it to obtain shares of skilled per age class. We proceed as follows. First, it is reasonable to assume that, at each period, the share of skilled individuals is higher for the younger age class. In particular, we assume that the share of skilled individuals aged 85 to 94 corresponds arbitrarily to $80 \%$ of the share of skilled aged 75 to 84 , which in turn is equal to $80 \%$ of that of the next younger age class, and so forth. As all the shares of skilled per age class then depend on the share of skilled aged 25 to 34 , we compute this share in order to matches the total share of skilled in 1950, as given by the Barro-Lee Dataset. Second, we report the values of the shares of the age classes 25-34 to 65-74 of the following years. For example, the share of skilled aged 35 to 44 in 1960 is equal to the share of skilled aged 25-34 in 1950, as we assume that the skilled and less-skilled individuals have the same probability to be alive at the beginning of each period. Third, for all the following years, we compute the share of skilled aged 25 to 34 in the same way as for the year 1950. Lastly, the share of skilled aged 15 to 24 in 1950 is simply equal to the share of skilled aged 25 to 34 in 1960 .

${ }^{22}$ North-to-North and South-to-South migrants are implicitly dealt with through the U.N. population data and forecasts.
} 
strategy is based on the proportion of total immigrant stock to total resident population observed in each of the three developed regions.

For year 2000, the number, the age structure, and the skill type (proxied by educational attainment) of immigrants are calibrated using published statistics in the U.N. and the Docquier-Marfouk (2006) datasets. From the gross stock of immigrants in each developed region, we subtract migrants aged 0-14 and all North-to-North migrants, then we compute the shares of immigrants by skill and by region of origin. Anchored to the 2000 numbers, we use survival probabilities as well as the growth rates of the immigrant population to construct the retrospective numbers of migrants before 2000 . For immigration forecasts, we start from the 2000 numbers and let migrants die according to the survival probability forecasts. Assuming that all future migrants are aged 15-24, we let changes in the stock of immigrants follow the U.N. forecasts (from which we subtract those aged 0-14 and North-to-North migrants using the 2000 proportions). It is assumed that future migrants are distributed by skill and by region as they are in 2000 .

Naturally, demographic evolution affects an economy's support ratio, which is defined here as the ratio of resident labor force to resident population: ${ }^{23}$

$$
S R_{t}=\frac{\sum_{a=0}^{7} \sum_{j=\{s, l\}} \lambda_{a, t}^{j} N_{a, t}^{j}}{\sum_{a=0}^{7} \sum_{j=\{s, l\}} N_{a, t}^{j}} .
$$

Figure 3.a depicts its baseline evolution. It is observed that all regions will be affected by the aging process, thus experiencing shrinking shares of workingage population, with EAS facing the lowest support ratio and SSA the highest at all periods. Except for SSA, the decline of support ratio levels off around 2050, and from then on, the share of working population actually begins to climb up in some regions, most notably in EAS, RUS, and to a lesser degree in CHI.

$\odot$ Brain drain versus brain gain: As mentioned in Section 1, a recent wave of theoretical and empirical studies suggest that skilled emigration can generate a positive incentive effect on human capital formation, which may outweigh the loss of human capital due to brain drain, especially in countries with low skilled emigration rates. At the baseline, it is considered that the

\footnotetext{
${ }^{23}$ Notice that $m_{t-1}$ in Eq. (2) already takes into account population changes due to migration; therefore, $N_{a, t}$ measures the resident population of age class $a$ at period $t$.
} 
net effects of skilled emigration on human capital formation are already embodied in the calibration based on real data. The resident human capital level, measured as the proportion of skilled in the resident labor force, is

$$
H C_{t}^{r s}=\frac{\sum_{a=0}^{7} \lambda_{a, t}^{s} N_{a, t}^{s}}{\sum_{a=0}^{7} \sum_{j=\{s, l\}} \lambda_{a, t}^{j} N_{a, t}^{j}} .
$$

Figure 4.a depicts its baseline evolution by region.

In order to incorporate the "brain gain" effect in computing the aftershock levels, we follow Beine et al. (2008a), who find evidence that the prospect of skilled emigration is positively associated with gross (premigration) human capital levels in cross-country regressions. To begin with, we build on Docquier and Marfouk (2006)'s data and compute the relative changes in skilled emigration rates $\left(\Delta m_{t}^{s} / m_{t}^{s}\right)$ resulted from the rise in emigration flows to the North. At the baseline, the gross human capital level at period $t$, measured as the proportion of skilled among natives (including emigrants and residents), is computed according to

$$
H C_{t}^{n t}=\frac{\left(1-m_{t}^{l}\right) H C_{t}^{r s}}{1-m_{t}^{s}\left(1-H C_{t}^{r s}\right)-m_{t}^{l} H C_{t}^{r s}},
$$

which is a transformation of Eq. (6) in Beine et al. (2008a), and $m_{t}^{l}$ denotes the less-skilled emigration rate. Then, we use the brain gain elasticity estimated in their parsimonious specification:

$$
\frac{\Delta H C_{t}^{n t}}{H C_{t}^{n t}} \cdot \frac{m_{t}^{s}}{\Delta m_{t}^{s}}=0.0481
$$

to obtain the after-shock level of gross human capital, which is then transformed back to the after-shock level of resident human capital. ${ }^{24}$

$\odot$ Propensity to remit: The calibration strategy for the propensity to remit, or $\gamma^{j}$ in Eq. (5), is based on the officially recorded remittances to GDP ratio for each developing region (see Table 1). Due to data availability, we do not have information on the potential heterogeneity in propensities to remit

\footnotetext{
${ }^{24}$ Notice that, given the framework of eight overlapping generations, the change in resident human capital at period $t$ needs to be taken into account also in the next periods.
} 
between skill types. ${ }^{25}$ Neither do we know about the distributional pattern of remittance receipts in migrants' home country. ${ }^{26}$ It is assumed at the baseline that $\gamma^{s}=\gamma^{l}$ and that remittances are distributed equally among all residents living in the same developing region. ${ }^{27}$

$\odot$ Production parameters: The share of gross capital returns in the total domestic output, or $\alpha$ in Eq. (6), is set to one-third as estimated in the growth accounting literature à la Solow (1957).

The Harrod neutral technological progress $\left(A_{t}\right)$ is calibrated as follows. North America is assumed to be the technologically leading economy at all periods considered, with the level of technology denoted by $A_{t}^{N A M}$. Its evolution is calibrated with real observations up to year 2000, and for future periods, the annual growth rate is assumed to be equal to 1.84 percent. In order to obtain $A_{t}$ for non-leading regions, we use the observed paths of GDP ratio, $Y_{t} / Y_{t}^{N A M}$, where $Y_{t}^{N A M}$ measures the leader's GDP. We swap the exogenous variable $A_{t} / A_{t}^{N A M}$ for the endogenous variable $Y_{t} / Y_{t}^{N A M}$ and then solve the identification steps. ${ }^{28}$ The ratios of GDP's are computed by employing the WDI data of GDP per purchasing power parity for years 1980, 1990, and 2000, and the values in 1980 are adopted for the periods preceding 1980. For the periods following 2000, the calibration of the forecast technological progress will be discussed later when changes in resident human capital and

\footnotetext{
${ }^{25}$ While Ratha (2003) claims that skilled migrants send more remittances due to higher earnings, empirical evidence put forth by Faini (2007) and Nimii et al. (2008) suggest that, compared to their less-skilled counterpart, skilled migrants have a lower propensity to remit.

${ }^{26} \mathrm{On}$ the one hand, some studies find that remittances are distributed rather evenly among different income groups (e.g., Taylor and Wyatt, 1996) while others identify that inequality is deepened with migration and remittances (e.g., Barham and Boucher, 1998). On the other hand, the relationship between migration/remittances and inequality may be characterized by an inverse U-shaped pattern, suggesting that the short- and long-run effects may be of opposite signs (Stark et al., 1986; McKenzie and Rapoport, 2007; Shen et al., 2009).

${ }^{27}$ Notice, however, when calibrated to the official remittances data, it turned out to be infeasible that skilled migrants could have a much lower propensity to remit. Otherwise, remittances from less-skilled migrants will have to account for an unreasonably large share of total remittance receipts, which would then require that they remit an extremely large share of their total income.

${ }^{28}$ We follow the methodology developed in de la Croix and Docquier (2007). They use a backsolving identification method to calibrate total factor productivity (TFP) with the Dynare algorithm (Juillard, 1996).
} 
technology diffusion are explicitly taken into account. ${ }^{29}$

Following Acemoglu (2002), the elasticity of substitution between skilled and less-skilled labor $(\epsilon)$ is set to 1.4 , so the corresponding parameter $\sigma$ in Eq. (8) is equal to 0.2857. Regarding the skill-biased technical change $\left(v_{t}\right)$, the exogenous variable $v_{t} /\left(1-v_{t}\right)$ is swapped for the endogenous variable $w_{t}^{s} / w_{t}^{l}$ in Eq. (9) using the aforementioned procedure. Skill premiums in 2000 are arbitrarily fixed for each region. ${ }^{30}$ For the periods preceding 2000, the values vary according to the 1950-2000 pattern of college wage premiums in the United States (Acemoglu, 2003). For the periods following 2000, the values in 2000 are adopted.

$\odot$ Technological progress: In order to take into account the diaspora externality in enhancing technology diffusion from the North to the South (see Section 1), we follow Lodigiani (2008), who extended Vandenbussche et al. (2006) by adding skilled diaspora in their specification that estimates TFP growth fueled by a neo-Schumpeterian technological progress: ${ }^{31}$

$$
\begin{aligned}
\Delta \ln \left(T F P_{t}\right)= & 0.59-0.29 \cdot \ln \left(\frac{T F P_{t}}{T F P_{t}^{N A M}}\right)+1.44 \cdot H C_{t}^{r s} \\
& -0.10 \cdot \ln \left(M_{t}^{s}\right)+0.88 \cdot \ln \left(\frac{T F P_{t}}{T F P_{t}^{N A M}}\right) \cdot H C_{t}^{r s} \\
& -0.06 \cdot \ln \left(\frac{T F P_{t}}{T F P_{t}^{N A M}}\right) \cdot \ln \left(M_{t}^{s}\right)+\mu_{t}
\end{aligned}
$$

where $T F P_{t} \equiv A_{t}^{1-\alpha}$ in Eq. (6), and $\left(T F P_{t} / T F P_{t}^{N A M}\right)$ is a monotonic transformation of a region's distance to the technology frontier $\left(A_{t} / A_{t}^{N A M}\right)$. $\Delta \ln \left(T F P_{t}\right)$ denotes the rate of TFP growth between year $t$ and year $t+5$. $M_{t}^{s}$ is a developing region's stock of skilled emigrants living in the North. ${ }^{32}$ Finally, $\mu_{t}$ captures the exogenous time trend. The basic idea lying behind this specification is that TFP growth is determined by a region's capacity

\footnotetext{
${ }^{29}$ For ADV and JAP, the values in 2000 are adopted for all periods following 2000.

${ }^{30}$ The skill wage premiums in 2000 are: 2.35 for ADV, 3 for NAM, JAP, EAS, and MEN, 3.15 for LAC, 3.25 for RUS, CHI, and IND, and finally 3.5 for SSA.

${ }^{31}$ Using a similar framework, Papageorgiou and Spilimbergo (2009) identify that foreigneducated students also facilitate technological diffusion back to their home countries.

${ }^{32}$ It is implicitly assumed that, as the skilled diaspora located in NAM, skilled emigrants living in JAP and in ADV have the same externality in diffusing modern technologies. We regard it as a safe assumption given their narrow technology gaps to NAM.
} 
to innovate or to adopt modern technologies. On the one hand, in a technologically less-advanced region that rely on the adoption of technologies innovated in the North, skilled emigrants facilitate technology diffusion back to the South; thus, it helps to augments TFP growth. ${ }^{33}$ On the other hand, however, skilled human capital is crucial for technology innovation but also for the adoption of technologies diffused from the North; therefore, brain drain negatively affects TFP growth, and this effect is especially pessimistic for regions far from the technological frontier because of its inability to innovate and lack of skilled workers to adopt modern technologies.

As mentioned earlier, changes in resident human capital and the diaspora externality in technology diffusion are explicitly taken into account for the forecast of the Harrod neutral technological progress, i.e., from period 2000 onwards. The forecasts of migration and of resident human capital are plugged into the above estimation in order to predict the evolution of $T F P_{t}$, which is then transformed into $A_{t}$; moreover, we consider that $\mu_{t}$ is equal to zero everywhere except in EAS, CHI, and IND, where the exogenous trends remain positive until $2050 .{ }^{34}$ The baseline evolution of $A_{t} / A_{t}^{\text {NAM }}$ is depicted in Figure 5.a.

$\odot$ Risk premium: As discussed in Section 1, skilled diaspora may contribute to reducing information-related risks for capital investments in the migrants' home countries, and thus attracting more FDI inflows in the South. This dynamic complementarity is captured as follows:

$$
\text { If } \begin{array}{rlrl}
M_{t}^{s}>M_{t-1}^{s}, & \left(1+\pi_{t+1}\right) & =\left(1+\pi_{t}\right) \cdot\left(1-\phi \cdot \frac{M_{t}^{s}-M_{t-1}^{s}}{M_{t-1}^{s}}\right) ; \\
\text { otherwise, } & \pi_{t+1}=\pi_{t} .
\end{array}
$$

\footnotetext{
${ }^{33}$ Docquier and Rapoport (2009) point out that the log-specification of diaspora externality in Lodigiani (2008) leads to counter-intuitive results that technology diffusion is very strong in small countries. Our aggregate approach makes this misspecification a very minor problem when making cross-region comparisons; however, it may imply that the positive effect generated through technology diffusion is to some degree underestimated. However, we choose to follow this specification as it is the only existing empirical study that is highly compatible with our model.

${ }^{34}$ Over the period 1950-2000, we calibrate $\mu_{t}$ so that the baseline simulations perfectly match the observations of GDP ratios, $Y_{t} / Y_{t}^{N A M}$. The calibrated path for $\mu_{t}$ is rather stationary and distributed around zero in all regions except for EAS, CHI, and IND, where positive trends are observed. Due to data availability in calibration, $A_{t}^{R U S} / A_{t}^{N A M}$ is assumed to remain constant from 2000 onwards.
} 
$-\phi \equiv-\theta(1-\alpha)\left(F D I_{t} / K_{t}\right)$ is the elasticity of risk premium to the lagged size of skilled diaspora. ${ }^{35} \theta$ is defined and estimated in Docquier and Lodigiani (2009)'s panel regression as

$$
\frac{\Delta f d i_{t}}{f d i_{t}} \cdot \frac{M_{t-1}^{s}}{\Delta M_{t-1}^{s}}=0.025
$$

with $f d i_{t}$ denoting FDI per worker, so $\theta$ is its elasticity to the lagged size of skilled diaspora. $\left(F D I_{t} / K_{t}\right)$ is set to 12.5 percent, which is approximately the average share of FDI among total investments in developing countries.

We anchor the evolution of risk premium to the 2000 values, which are calibrated with the OECD's Country Risk Classification. ${ }^{36}$ For the periods preceding 2000, the values in 2000 are adopted. For the periods following 2000, the migration forecast is plugged into Eq. (11) to obtain the evolution of risk premium, which is then depicted in Figure 6.a.

\subsection{The demographic shock of additional skilled emigration}

Starting from the U.N. forecasts, in each decennial period from 2010-20 to 2050-60, the demographic shock constitutes a 20 percent increase in the forecast flow of skilled migrants from every developing region to each developed region. Consistent with the model assumption, the additional migrants are considered to belong to the age class $a=0$, or aged $15-24 .{ }^{37}$ Notice, however, it is implicitly assumed in our aggregate approach that all changes induced by the five waves of emigration shocks are homogeneously experienced by every country within the same region. Hence, the simulated changes per

\footnotetext{
${ }^{35}$ The definition of $\phi$ is derived from the combination of $\left(1+\pi_{t+1}\right)=\left(1+\pi_{0}\right)\left(M_{t}^{s}\right)^{-\phi}$ and Eq. (7).

${ }^{36}$ It is based on the Knaepen Package, a system for assessing country credit risk and classifies countries into eight country risk categories, from no risk (0) to high risk (7). Basically, it measures the credit risk of a country. There are no risks for the three developed regions whereas the risk classifications in 2000 for each of the seven developing regions are as follows: 3.4 for EAS, 4.0 for MEN, 5.2 for LAC, 6.4 for SSA, 6.2 for RUS, 3.2 for $\mathrm{CHI}$, and 4.9 for IND. In order to transform these values into risk premiums, we use the formula: $\pi_{2000}=0.37 \cdot(R C / 7)$, where $R C$ denotes a region's risk classification and $\max \left(\pi_{2000}\right)=0.37$ is based on the calibration to Caselli (2007), who finds that the average returns to capital are about 1.25 times higher in developing than in developed economies, after correction for price differences.

${ }^{37} \mathrm{~A}$ skilled young migrant is a young adult who is forecast to complete post-secondary education, regardless of where the degree is awarded.
} 
developing region are in effect more indicative of those experienced by large countries, due to their heavier weight in the aggregation. Below, we discuss how the demographic shock changes some key regional characteristics from the baseline. We focus on the transitional period 2000-2100, or the period before the first wave of additional migrants is introduced until the period when the additional migrants of the last wave are entirely retired.

Figure 3.b shows the relative changes in support ratio $\left(S R_{t}\right)$. As expected, all regions are adversely affected by the loss of working-age population caused by the demographic shock that alters population dynamics via $m_{t}$ in Eq. (2). However, EAS experiences the greatest impact due to the combination of a relatively large share of aged (hence non-working-age) population and a high skilled emigration rate among its rather educated populace. The impacts reach their respective maxima in 2060, with EAS confronted by a decline of $0.65 \%$.

Regarding resident human capital $\left(H C_{t}^{R S}\right)$, Figure 4.b depicts its relative changes. It is observed that, after the initial shocks, increased skill outflows negatively affect the skill composition among the young generation, or $\phi_{t}$ in Eq. (3). Hence, resident human capital is decreased, in particular for regions characterized by distinctively high skilled emigration rates, namely EAS, LAC, and SSA (see Table 1). However, the incentive effect of better skilled migration prospects on human capital formation (or the brain gain effect) eventually benefit all regions, enhancing resident human capital by maximally $2-3 \% .^{38}$

As discussed earlier, resident human capital and skilled diaspora are crucial determinants of technological progress (see Eq. (10)). Figure 5.b plots the relative changes in the Harrod neutral technological progress with respect to the leader's $\left(A_{t} / A_{t}^{N A M}\right)$. Small positive effects are observed in MEN and IND, both with relatively low skilled emigration rates and located far from the technology frontier. For them, the enlarged skilled diaspora in the North acts to facilitate the diffusion of more advanced technology back to the South. In comparison, the initial losses of resident human capital observed in EAS, LAC, SSA, and CHI have negative dynamic impacts on their capacity to innovate or to adopt modern technologies; ${ }^{39}$ meanwhile, the compensatory

\footnotetext{
${ }^{38}$ As our aggregate approach has the effects in every region dominated by the large countries, this result is consistent with Beine et al. (2008a)'s findings about winners and losers of brain drain, where "the most populated countries [. . .] are all among the winners."

${ }^{39}$ For CHI, its distance to the technological frontier is not low enough for it to benefit
} 
role played by skilled diaspora in technology diffusion is of less importance for technologically more advanced regions, e.g., EAS as well as CHI in the second-half of the $21^{\text {st }}$ century. Although larger than the positive effects, the negative relative changes still lie well below $1 \%$.

Finally, Figure 6.b describes the relative changes in risk premium $\left(\pi_{t}\right)$ on capital returns. It is found that, through the enlarged diaspora, all developing regions benefit from reductions in risk premiums, which will then imply ceteris paribus greater FDI inflows in the open economy. The relative changes in 2060 range between $0.16-0.27 \%$.

\section{Results and Analysis}

This section presents and analyzes the simulated results of the ten-region calibrated OLG model, where all the mechanisms discussed in the previous section are incorporated into a unified generic framework, with the direct effects of skilled emigration propagated and the indirect effects endogenously and dynamically generated. By introducing the demographic shock of additional South-to-North brain drain specified above, we would like to answer the following questions: (i) What are the impacts on the developing economies when they are faced with larger skill outflows? (ii) Which channels are more dominant? Do they induce positive or negative impacts on the South, and under which conditions? The assessment of the overall impacts is conducted by comparing three economic indicators at the baseline and after shocks. These indicators are defined as follows:

- GDP per capita: $Y_{t} / N_{t}$.

- GNI per capita: $G N I_{t} / N_{t}$, where $G N I_{t}=Y_{t}+$ remittance receipts $_{t}+$ net capital income inflows $t$

much from the diaspora externality on technology diffusion, but it is sufficiently low for it to suffer greatly from the loss of skilled workers. This is why CHI's technological progress is so adversely affected even though it faces only a slightly negative impact on resident human capital after the first wave of migration shock. Notice that CHI's inability to benefit much from technology diffusion is rather at odds with Kerr (2008)'s finding that China is the main beneficiary from the U.S. innovations. This may be again due to the mis-specification problem mentioned in Footnote 33 given that $\mathrm{CHI}$ has the largest skilled diaspora at all periods along the transitional path. 
+ foreign $\operatorname{aid}_{t}-$ consumption $\operatorname{taxes}_{t}{ }^{40}$

- Skilled-to-less-skilled income inequality: $\left(G N I_{t}^{s} / N_{t}^{s}\right) /\left(G N I_{t}^{l} / N_{t}^{l}\right) .{ }^{41}$

To begin with, we examine how the shock of additional skilled emigration affects GDP per capita through different channels. As a matter of fact, the total impact can be disentangled by the changes in the four regional characteristics discussed in Section 2.3.

\subsection{Disentangled effects on GDP per capita}

The disentangled effects of the demographic shock on GDP per capita are depicted in Figure 7 by each channel.

Demography $\left(m_{t}\right)$ : The loss of working-age population accelerates the aging process and results in a lower support ratio. In other words, with each migration shock, it implies a downsized domestic production yet proportioned by the same number of retirees. Hence, GDP per capita is negatively affected in all regions, with the maximal impacts reached in 2060 and ranged between $0.2-0.7 \%$. Consistent with the impact on support ratio, EAS is the hardest hit region through the demography channel.

Human Capital $\left(\phi_{t}\right)$ : It is observed that the incentive effect of brain drain, which eventually contributes to "brain gain" in all regions via more human capital formation, also improves GDP per capita. For most regions, this positive impact begins to level off in 2060, with RUS benefiting the most at $1.0 \%$ and SSA the least at $0.2 \%$. In line with the relative changes in resident human capital, the adverse short-run impacts are more severe in regions characterized by high skilled emigration rates. ${ }^{42}$ In comparison, the medium-to-long-run benefits of the incentive effect are most visible in regions

\footnotetext{
${ }^{40}$ Net capital income inflows are calculated as the value of residents' assets subtracted by the returns to capital used in domestic production.

${ }^{41}$ The definition of $G N I_{t}^{j}, j=\{s, l\}$, is analogous to $G N I_{t}$, except that (residents' labor income $_{t}^{j}+$ residents' asset value $t_{t}^{j}$ ) is used in place of $Y_{t}$.

${ }^{42}$ In order to single out the impact of the incentive effect, all parameter values are held at the baseline, except $\phi_{t}$. Because of the assumption outlined in Section 2 that the skilled youth do not fully participate in the labor market, the initial increases in $\phi_{t}$ due to migration shocks imply that there are less efficient labor $\left(L_{t}\right)$ available for production. This is why even those regions characterized by low skilled emigration rates are also negatively impacted in the beginning of the $21^{\text {st }}$ century in Figure 7.b.
} 
where the labor force is better skilled, including EAS and LAC where the negative short-run impacts are actually the greatest.

Technological progress $\left(A_{t}\right)$ : Since the Harrod neutral technological progress has the multiplier effect on domestic outputs (see Eq. (6)), its impacts on GDP per capita naturally follow the pattern of relative changes in technological progress discussed in Section 2.3, with MEN and IND seeing positive effects up to $0.1 \%$ and $0.3 \%$ respectively thanks to technology diffusion that increases the efficiency of the production factors. In the mean time, those regions suffering initially from the loss of resident human capital have to cope with long-lasting negative dynamic impacts on their capacities to innovate or to adopt modern technologies; therefore, with the undermined production efficiencies, returns to capital decline, which discourages capital investments in these regions. LAC and CHI are most seriously affected in this respect, with their GDP per capita dwindled by about $0.9 \%$ maximally. ${ }^{43}$

Risk premium $\left(\pi_{t}\right)$ : In an open economy, the level of risk premium is one of the crucial factors that determine the volume of physical capital invested in domestic production. As every region experiences reduced risk premium with the enlargement of diaspora, they also enjoy increases in GDP per capita through this channel. It is observed that the positive effects impact nearly all regions with similar magnitudes, ranging between $0.01-0.03 \%$ in 2060 . EAS benefits slightly less because, under the migration shocks, its diaspora has a smaller relative increase in size (see Eq. (11)). Note that this effect is rather small in the short-run; nonetheless, it grow larger with accumulative migration shocks and its impacts are long-lasting.

Now that we have understood better the channels through which the demographic shock of additional brain drain impacts GDP per capita. We proceed further to the discussion of total impacts on the three economic indicators.

\subsection{Total impacts on GDP per capita}

Figure 8.a presents the total impacts of the demographic shock on GDP per capita. In the medium-to-long-run, it is found that all the seven developing regions either enjoy increased GDP per capita or face very slightly

\footnotetext{
${ }^{43}$ However, we believe that the total impact of brain drain on $\mathrm{CHI}$ through the technology channel may be largely downward biased, due to the problem of mis-specification in the adopted empirical equation. See the discussion in Footnotes 33 and 39.
} 
negative impacts, thanks to the dynamic incentive effect on human capital formation and to the gradual reductions of risk premium. Nevertheless, while some experience positive impacts already in the short-run (i.e., MEN, RUS, IND, with $0.3-0.6 \%$ increases in 2060), others have to first undergo long periods of economic downturn along the transitional path (i.e., EAS, LAC, SSA, and CHI, with $0.4-0.7 \%$ decreases in 2060). Except for RUS, what distinguishes the winners from the losers in the shorter run is the impacts working through the technology channel, which is closely related to a region's resident human capital and its distance to the technological frontier. It is observed that all the loser regions suffer from the dynamic impacts on technological progress originating from the initial losses of their resident human capital as depicted in Figure 4.b. Besides CHI, all other loser regions have distinctively high skilled emigration rates, which are also the characteristics of the regions that are less likely to enjoy brain gain according to Beine et al. (2008a).

Hence, in Figure 8.b, we run an alternative simulation where we abstract from the incentive effect on human capital formation. The total impacts are far more pessimistic, with all regions benefit less/ suffer more from the migration shocks (with $0.0-0.3 \%$ increases and $0.3-2.1 \%$ decreases in 2060). In 2100, only MEN and IND remain as the beneficiaries in terms of GDP per capita. Yet, the benefits are to a much lesser extent and still owed to technology diffusion through their enlarged skilled diaspora. In addition, EAS, LAC, SSA, and CHI are now faced with non-negligibly negative impacts even in the medium-to-long run, which range between $0.3-1.5 \%$ in 2100 .

However, human capital, or labor inputs in general, is not the only factor used in the production of goods, but physical capital also plays an indispensable role. As mentioned in Section 1, the traditional trade theory predicts that in an open economy skill outflows are accompanied by capital flight, whereas the recent empirical literature suggests a dynamic complementary link between migration and FDI inflows. Thus, it is important to gauge the effect that is attributed to international capital flows, which respond endogenously to the migration shocks and their direct impacts. In order to achieve this aim, an alternative simulation is run with restricted flows of physical capital, which means that the demographic shock has no impacts on the amount of physical capital available in each region nor on risk premiums that are associated with FDI inflows. ${ }^{44}$ Figure 8.c presents the after-shock

\footnotetext{
${ }^{44}$ In other words, $K_{t}$ and $\pi_{t}$ are held at the baseline levels.
} 
consequences under this scenario. The total impacts are now dictated by the channels of demography and of human capital, which jointly determine the total efficient labor available for domestic production. Moreover, whether positive or negative, the impacts become of smaller magnitudes, with EAS being the salient loser in the shorter run mainly due to its large share of senior residents.

It is worth being pointed out, however, that in this scenario the relative changes in technological progress remain the same as calibrated before. ${ }^{45}$ Its loss of influence when capital flows are restricted thus suggests that the technology channel works mainly through changes in capital investments in domestic production. Take LAC and CHI for example, the two regions most adversely impacted in terms of relative changes in technological progress and also the top two short-run losers in the usual calibration shown in Figure 8.a. It is found that, when capital flows do not react to changes in interregional differences in returns to capital caused by changes in production efficiency, the negative impact on LAC's GDP per capita is downsized from $0.7 \%$ to $0.1 \%$ in 2060 , and for CHI, the negative impact of $0.7 \%$ is entirely annulled. This alternative scenario teaches us a very important lesson, as it indicates that studies of brain drain in globalization shall not merely look at its direct implications on human capital and other economic determinants on which human capital have causal effects. As brain drain affects the economic environment in the South, other factor flows will respond to these changes and may act to magnify the total impacts of brain drain (e.g., through changes in technological progress) or to alleviate the negative effects (e.g., through increased FDI inflows attracted by lower risk premiums).

Finally, given the recent evidence that the skilled may have lower propensity to remit (see Section 2.2), another alternative simulation is conducted assuming the shock of additional skilled emigration does not add to the amount of remittance receipts. As shown in Figure 8.d, the total impacts are very much identical to the results with the usual calibration. ${ }^{46}$ In other words, in terms of domestic production in the developing regions, the impacts of brain drain and its direct and indirect effects are hardly altered by remittance receipts. This is not a surprising outcome because: first, not

\footnotetext{
${ }^{45}$ See Figure 5.b.

${ }^{46}$ In fact, the total impacts do become slightly more pessimistic when the additional skilled emigrants send back no remittances, but the differences in magnitudes are nearly undetectable.
} 
all remittances are invested in productive activities; second, capital mobility implies that the remittance-funded investments do not necessarily take place in the South, but conform to international arbitrage.

\subsection{Total impacts on GNI per capita}

The total impacts of the demographic shock on GNI per capita are depicted in Figure 9.a. Compared to the total impacts on GDP per capita, the general picture is slightly more optimistic. While the short-run winners and losers remain the same, the magnitudes of negative impacts are decreased (from $0.4-0.7 \%$ to $0.1-0.5 \%$ in 2060 ) whereas the scale of positive impacts are increased (from $0.3-0.6 \%$ to $0.6-0.8 \%$ in 2060 ). Recall the definition of GNI that it comprises of domestic outputs, remittances receipts, residents' foreign assets, and so on. Hence, the similar patterns between the total impacts on GNI per capita and on GDP per capita suggest that the dominant channels remain the same as those dictate the impacts on domestic production, i.e., the major effects work through changes in resident human capital and in technological progress. This can be confirmed by the results shown in the two alternative simulations: one lacks the incentive effect on human capital formation (see Figure 9.b) and the other has restricted flows of physical capital that buffer the South from the impacts on production efficiency (see Figure 9.c).

However, the additional remittance receipts, which have a dynamic effect to raise residents' assets via saving, act to improve the welfare of those left behind. The importance of the role played by remittances can be gauged in Figure 9.d. It is observed that, in relation to the simulation with the usual calibration, all regions are adversely affected in the alternative scenario where the skilled have lower propensity to remit, although some suffer more and others less. Take the period 2060 for example. MEN and SSA are the hardest hit regions because they receive relatively large amounts of remittances with respect to their GDP (see Table 1). While MEN sees the positive impact on its GNI per capita dwindled from $0.6 \%$ to $0.4 \%$, SSA has the total impact changed from $-0.1 \%$ to $-0.3 \%$.

\subsection{Total impacts on skilled-to-less-skilled income inequality}

Since brain drain does not only impact the overall economic outcome but also entails distributional effects, it is important to study how the skilled-toless-skilled income inequality is affected by the migration shocks. Figure 10.a 
depicts the total impacts with the usual calibration, while Figures 10.c to d present the results under the alternative simulations as described before.

Consistent with the model where skilled and less-skilled labor are imperfect substitutes (see Eq. (8)), it is found that the total impacts on inequality are dictated by the human capital channel: income inequality decreases (by $0.6-1.8 \%$ in 2060) due to the declined skill wage premiums resulted from a positive change in resident human capital, and vice versa. This is specifically confirmed in the alternative scenario that lacks the incentive effect on human capital formation: in Figure 10.b, all developing regions experience rising income inequality (by $0.2-1.0 \%$ in 2060) due to larger skill outflows, which is in contrary to all other scenarios where "brain gain" eventually leads to a smaller income gap between skill types. Moreover, since regions with high skilled emigration rates (e.g., EAS, LAC, and SSA) are less likely to benefit from brain gain at least in the short-run, they are also the regions witnessing short-run rises in income inequality when the incentive effect is present.

\section{Conclusion}

Many concerns as well as hopes have been raised over the issue of brain drain, in particular skill outflows from the developing South to the developed North. On the one hand, the direct impact of losing skilled human capital and its potentially negative externality may do harms to domestic production and adversely affect those left behind in the developing economies. On the other hand, recent empirical studies have demonstrated a series of positive feedback effects, suggesting that skilled emigration may inspire more human capital formation and that, on top of remittances, emigrants may contribute to the home economy through diaspora externalities.

The novelty of this paper is to construct a unified generic framework that is capable of combining many direct impacts of brain drain; moreover, their interactions and other indirect effects are also endogenously and dynamically generated. In this fashion, the framework is able to assess the global effects of brain drain on developing economies and to quantify the relative sizes of various static and dynamic impacts. Furthermore, it allows us to incorporate many essential channels, such as age structure and capital flows, through which brain drain may impact the developing economies in a direct and/or an indirect manner, whereas they are usually not studied in a less comprehensive partial equilibrium setting. 
It is identified that the short-run impact of brain drain on resident human capital is extremely crucial, since it does not only determine the number of skilled workers available to domestic production, but it also affects an economy's capacity to innovate or to adopt modern technologies, which acts to determine the production efficiency and greatly influence the volume of capital in- and out-flows. Therefore, it follows that, when the incentive effect on human capital formation is absent, economies in all the sending regions become very much worse off (see Figure 11.a). Moreover, the impacts working through the technology channel on production efficiencies are magnified in the open economy where capital investments conform to international arbitrage. Thus, when flows of physical capital are restricted, it is observed that those regions experiencing positive impacts on GDP per capita now enjoy more limited benefits, whereas the regions suffering from slowdowns in technological progress are more insulated from foreign capital retreat and native capital flight (see Figure 11.b).

Moreover, although not all remittance receipts are invested in the domestic production, the extra income received from migrants abroad is nonnegligible in improving the welfare of those left behind. Consequently, if skilled migrants have a lower propensity to remit than their less-skilled counterpart as concluded by some empirical studies, the beneficial effect of brain drain through remittances on GNI per capita will then be reduced (see Figure 11.c), and the impact scales of brain drain on income in the South will be mainly determined by its impacts on GDP per capita. Regarding the impacts of brain drain on the skilled-to-less-skilled income inequality, it is dictated by the skill composition of resident human capital; as a result, whether a region enjoys "brain gain" also implies whether its income inequality is decreased or not. Without the presence of the incentive effect on human capital formation, every region will witness an enlarging income gap between skilled and less-skilled workers (see Figure 11.d).

As mentioned in Section 2.3, our aggregate regional approach implies that the simulated results are more indicative of those experienced by large countries. Despite this disadvantage, the aggregate results still provide significant implications also on the per country basis. Given the importance of how brain drain impacts resident human capital in the short-run and its ensuing dynamic effects on technological progress, it can be concluded that countries with high skilled emigration rates are the most vulnerable to increased skilled emigration, as Beine et al. (2008a) provides evidence that they are the least likely to benefit from "brain gain" out of brain drain. They are composed of 
a long list of developing countries, especially in sub-Saharan Africa, Central America, and also many small states. Moreover, although international capital mobility rewards the developing economies with enhanced technological progress, it also magnifies the harms done by brain drain to other sending economies by discouraging capital investments away from the negatively impacted regions in terms of technology.

Hence, is brain drain a curse or a boon? There is not a uniform answer, and it varies with the sending country's characteristics. For example, in Eastern European countries, brain drain does not only negatively affects its short-run huamn capital, but it also significantly increases the burden of their working-age residents to support the relatively large share of retirees. Besides, for the technologically less-advanced countries where skilled emigration is not a prevalent phenomenon, brain drain may not be an unwelcome event not only because it has the potential to raise resident human capital, but also because their skilled diaspora may facilitate the diffusion of up-to-date technologies, which accelerates technological progress in these economies. However, the certain losers of brain drain are those countries that have already experienced large outflows of their skilled, and their loss is not alleviated but magnified as it takes place in a globalized world where skill outflows generate influences also upon other flows of factors, most notably physical capital.

Acknowledgements The authors gratefully acknowledge financial support from the Belgian Federal Government (PAI grant P6/07, "Economic Policy and Finance in the Global Economy: Equilibrium Analysis and Social Evaluation"), from the Belgian French-speaking community (Grant ARC 03/08-302 "New Macroeconomic Approaches to the Development Problem"), and from the European Commission (Marie Curie Research Training Network "Transnationality of Migrants"). We thank Hillel Rapoport for many insightful and valuable comments. All remaining errors are of course ours.

\section{References}

Acemoglu, D., 2002. Technical changes, inequaility, and the labor market. Journal of Economic Literature 40 (1), 7-72.

Acemoglu, D., 2003. Patterns of skill premia. Review of Economic Studies $70(2), 199-230$. 
Aglietta, M., Arezki, R., Breton, R., Chateau, J., Fayolle, J., Juillard, M., Lacu, C., Cacheux, J. L., Rzepkowski, B., Touze, V., 2005. Scenarios for global ageing: an investigation with the INGENUE 2 world model, ENEPRI Research Report No. 9.

Baffes, J., Mitchell, D., Riordan, E. M., Streifel, S., Timmer, H., Shaw, W., 2009. Global economic prospects 2009: commodities at the crossroads. The International Bank for Reconstruction and Development / The World Bank, Washington DC.

Barham, B., Boucher, S., 1998. Migration, remittances and inequality: estimating the net effects of migration on income distribution. Journal of Development Economics 55 (2), 307-331.

Barro, R. J., Lee, J.-W., 2001. International data on educational attainment: updates and implications. Oxford Economic Papers 53 (3), 541-563.

Beine, M., Docquier, F., Rapoport, H., 2001. Brain drain and economic growth: theory and evidence. Journal of Development Economics 64 (1), 275-289.

Beine, M., Docquier, F., Rapoport, H., 2008a. Brain drain and human capital formation in developing countries: winners and losers. Economic Journal 118 (528), 631-652.

Beine, M., Docquier, F., Schiff, M., 2008b. International migration, transfers of norms and home country fertility, IZA Discussion Papers No. 3912.

Bhagwati, J. N., 1972. The United States in the Nixon era: the end of innocence. Daedalus, 25-47.

Bhagwati, J. N. (Ed.), 1976a. The Brain Drain and Taxation, Vol. 2: Theory and Empricial Analysis. North-Holland, Amsterdam.

Bhagwati, J. N. (Ed.), 1976b. Taxing the Brain Drain, Vol. 1: A Proposal. North-Holland, Amsterdam.

Bhagwati, J. N., Hamada, K., 1974. The brain drain, international integration of markets for professionals and unemployment : A theoretical analysis. Journal of Development Economics 1 (1), 19-42. 
Bhagwati, J. N., Hamada, K., 1975. Domestic distortions, imperfect information and the brain drain. Journal of Development Economics 2 (3), 265-279.

Card, D., 2009. Immigration and inequality. American Economic Review $99(2), 1-21$.

Caselli, F., 2007. The marginal product of capital. Quarterly Journal of Economics $122(2), 535-568$.

Cervellati, M., Sunde, U., 2005. Human capital formation, life expectancy, and the process of development. American Economic Review 95 (5), 16531672 .

Chiquiar, D., Hanson, G. H., 2005. International migration, self-selection, and the distribution of wages: evidence from Mexico and the United States. Journal of Political Economy 113 (2), 239-281.

Clemens, M. A., Pritchett, L., 2008. Income per natural: measuring development for people rather than places. Population and development review 34 (3), 395-434.

Commander, S., Kangasniemi, M., Winters, L. A., 2004. The brain drain: curse or boon? A survey of the literature. In: Baldwin, R. E., Winters, L. A. (Eds.), Challenges to globalization: analyzing the economics. Chicago University Press, Chicago, Ch. 7, pp. 235-272.

de la Croix, D., Docquier, F., 2007. School attendance and skill premiums in france and the u.s.: a general equilibrium approach. Fiscal Studies 28 (4), $383-416$.

Defoort, C., 2008. Tendances de long terme en migrations internationales: analyse à partir de 6 pays receveurs. Population-F 63 (2), 317-352.

Docquier, F., Lodigiani, E., 2009. Skilled migration and business networks. Open Economic Review, in press.

Docquier, F., Lowell, B. L., Marfouk, A., 2009. A gendered assessment of highly skilled emigration. Population and Development Review, in press. 
Docquier, F., Marfouk, A., 2006. International migration by educational attainment (1990-2000). In: Ozden, C., Schiff, M. (Eds.), International migration, remittances and the brain drain. Palgrave-Macmillan, Washington, Ch. 5, pp. 151-199.

Docquier, F., Rapoport, H., 2009. Quantifying the impact of highly-skilled emigration on developing countries, mimeo, CEPR project, Fondazione Rodolfo Debenedetti.

Faini, R., 2007. Remittances and the brain drain: Do more skilled migrants remit more? World Bank Economic Review 21 (2), 177-191.

Freeman, R. B., 2006. People flows in globalization. Journal of Economic Perspectives 20 (2), 145-170.

Giuliano, P., Ruiz-Arranz, M., 2008. Remittances, financial development, and growth. Journal of Development Economics, in press.

Gould, D. M., 1994. Immigrant links to the home country: empirical implications for U.S. bilateral trade flows. Review of Economics and Statistics 76 (2), 302-316.

Grogger, J., Hanson, G. H., 2008. Income maximization and the selection and sorting of international migrants, NBER Working Paper No. 13821.

Haque, N. U., Kim, S.-j., 1995. Human capital flight: impact of migration on income and growth. IMF Staff Papers 42 (3), 577-607.

Head, K., Ries, J., 1998. Immigration and trade creation: econometric evidence from Canada. Canadian Journal of Economics 31 (1), 47-62.

Ivlevs, A., de Melo, J., 2008. FDI, the brain drain and trade: channels and evidence, CEPR Discussion Paper No. 7002.

Juillard, M., 1996. Dynare: a program for the resolution and simulation of dynamic models with forward variables through the use of a relaxation algorithm, CEPREMAP Working Papers No. 89602.

Kerr, W. R., 2008. Ethnic scientific communities and international technology diffusion. Review of Economics and Statistics 90 (3), 518-537. 
Kugler, M., Rapoport, H., 2007. International labor and capital flows: complements or substitutes? Economics Letters 94 (2), 155-162.

Lodigiani, E., 2008. Diaspora externalities and technology diffusion. Economie Internationale 3T (115).

McKenzie, D., Rapoport, H., 2007. Network effects and the dynamics of migration and inequality: theory and evidence from Mexico. Journal of Development Economics 84 (1), 1-24.

Miyagiwa, K., 1991. Scale economies in education and the brian drain problem. International Economic Review 32 (3), 743-759.

Mountford, A., 1997. Can a brain drain be good for growth in the source economy? Journal of Development Economics 53 (2), 287-303.

Nimii, Y., Ozden, C., Schiff, M., 2008. Remittances and the brain drain: skilled migrants do remit less, IZA Discussion Paper No. 3393.

Ottaviano, G. I., Peri, G., 2008. Immigration and national wages: clarifying the theory and the empirics, NBER Working Paper No. 14188.

Papageorgiou, C., Spilimbergo, A., 2009. Learning abroad and technology adoption, mimeo, International Monetary Fund.

Ratha, D., 2003. Workers' remittances: an important and stable source of external development finance. In: World Bank, Global Development Finance 2003. Palgrave McMillan, Washington, Ch. 7.

Shen, I.-L., Docquier, F., Rapoport, H., 2009. Remittances and inequality: a dynamic migration model. Journal of Economic Inequality, in press.

Solow, R., 1957. Technical change and the aggregate production function. Review of Economics and Statistics 39, 312-320.

Spilimbergo, A., 2009. Democracy and foreign education. American Economic Review 99 (1), 528-543.

Stark, O., 2004. Rethinking the brain drain. World Development 32 (1), 1522. 
Stark, O., Helmenstein, C., Prskawetz, A., 1997. A brain gain with a brain drain. Economics Letters 55 (2), 227-234.

Stark, O., Helmenstein, C., Prskawetz, A., 1998. Human capital depletion, human capital formation, and migration: a blessing or a 'curse'? Economics Letters 60 (3), 363-367.

Stark, O., Taylor, J. E., Yitzhaki, S., 1986. Remittances and inequality. Economic Journal 96 (383), 722-740.

Stark, O., Wang, Y., 2002. Inducing human capital formation: migration as a substitute for subsidies. Journal Public Economics 86 (1), 29-46.

Taylor, J. E., Wyatt, T., 1996. The shadow value of migrant remittances, income and inequality in a household-farm economy. Journal of Development Studies 32 (6), 899-912.

United Nations, D., 2001. World population prospects: the 2000 revision. United Nations, New York.

United Nations, D., 2009. World population prospects: the 2008 revision. United Nations, New York.

Vandenbussche, J., Aghion, P., Meghir, C., 2006. Growth, distance to frontier and composition of human capital. Journal of Economic Growth 11 (2), 97-127.

Vidal, J.-P., 1998. The effect of emigration on human capital formation. Journal of Population Economics 11 (4), 589-600.

Walmsley, T. L., Winters, L. A., 2005. Relaxing the restrictions on the temporary movement of natural persons: a simulation analysis. Journal of Economic Integration 20 (4), 688-726.

Wong, K.-y., Yip, C. K., 1999. Education, economic growth, and brain drain. Journal of Economic Dynamics and Control 23, 699-726. 
Figure 1: FDI inward (US\$ at current prices)

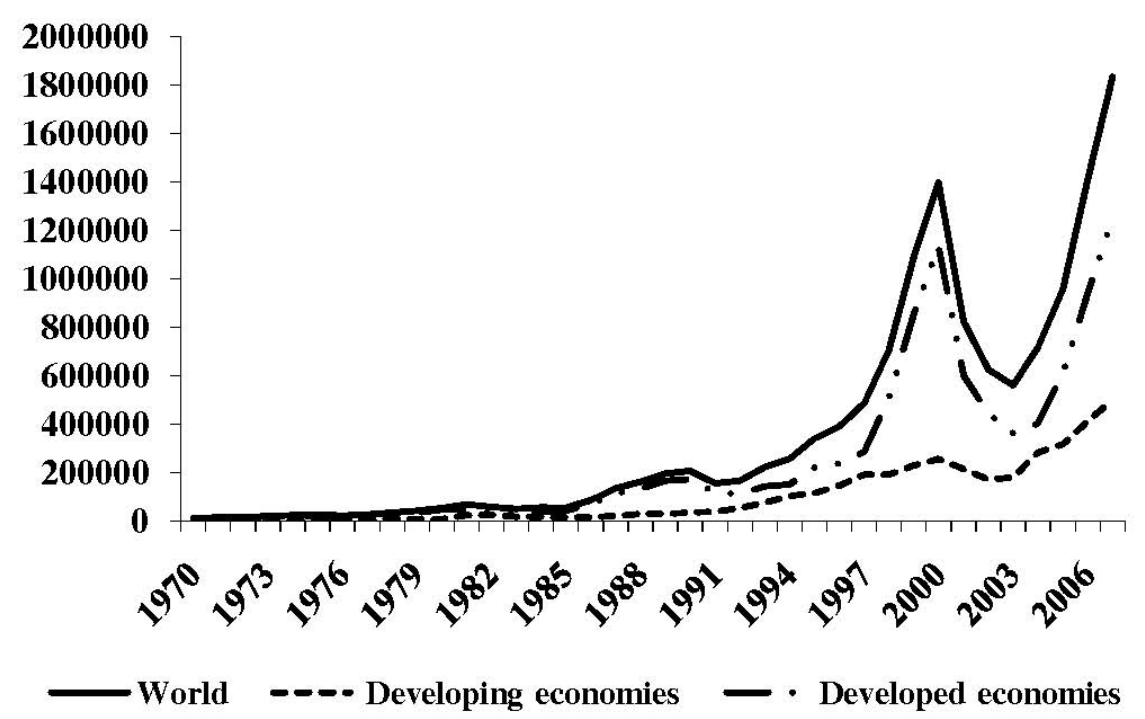

a. total (in millions)

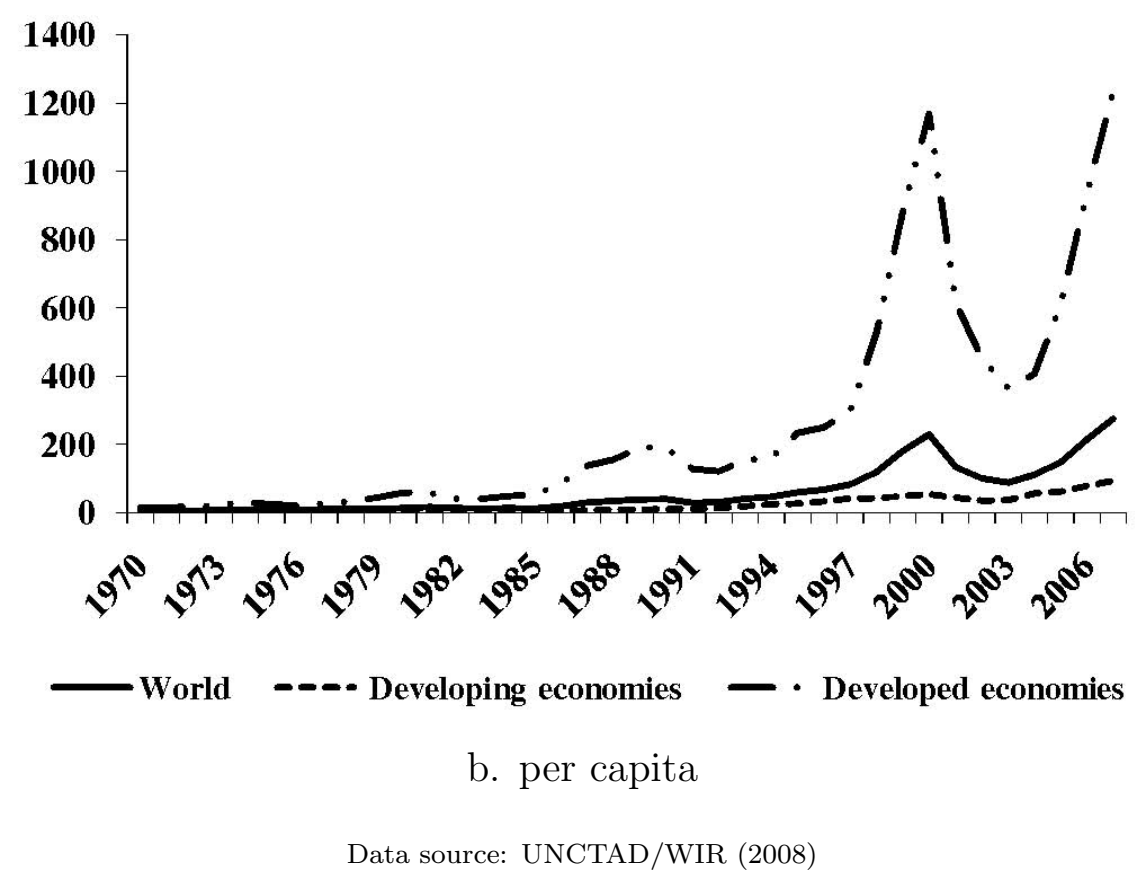


Figure 2: Positive Selection of International Migration

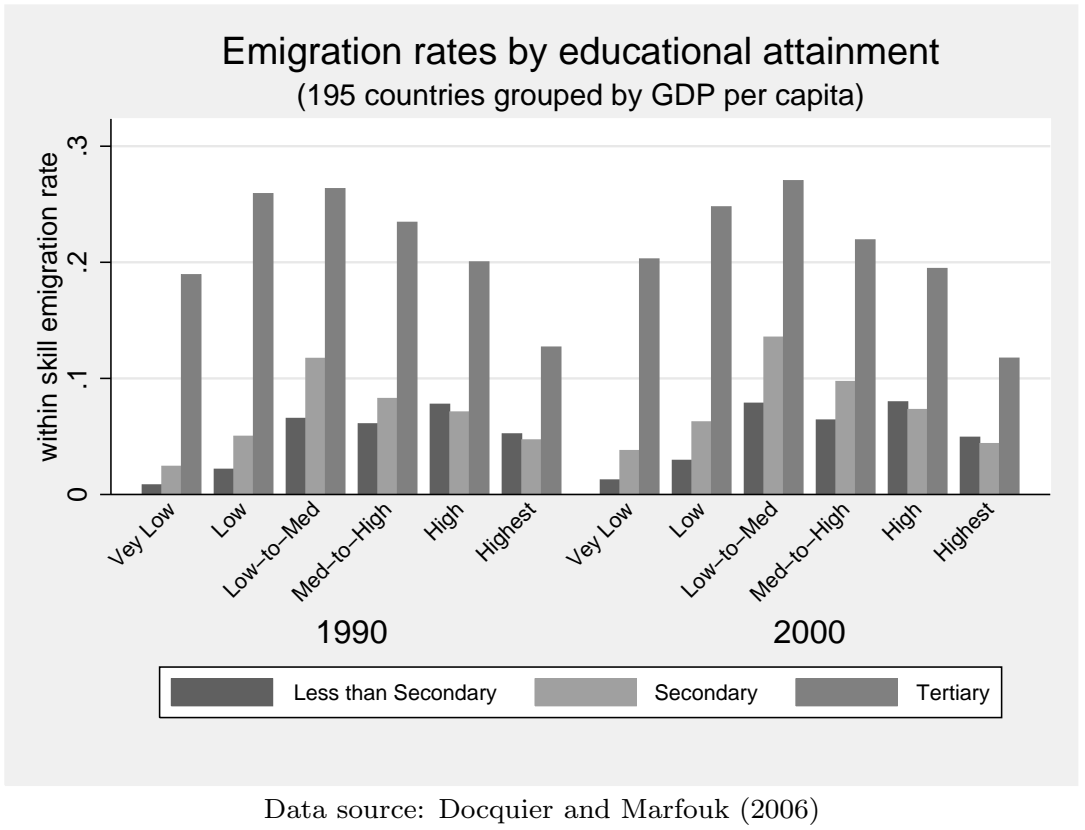




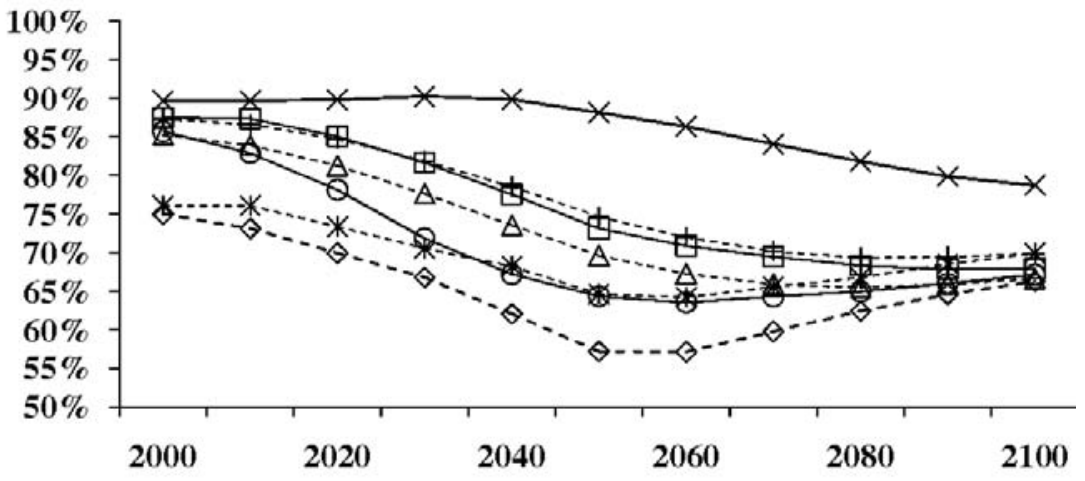

$-\diamond-$ EAS $\square$ MEN $--\Delta--$ LAC $\rightarrow$ SSA --*-- RUS $\multimap-$ CHI --+-- IND

a. Baseline value

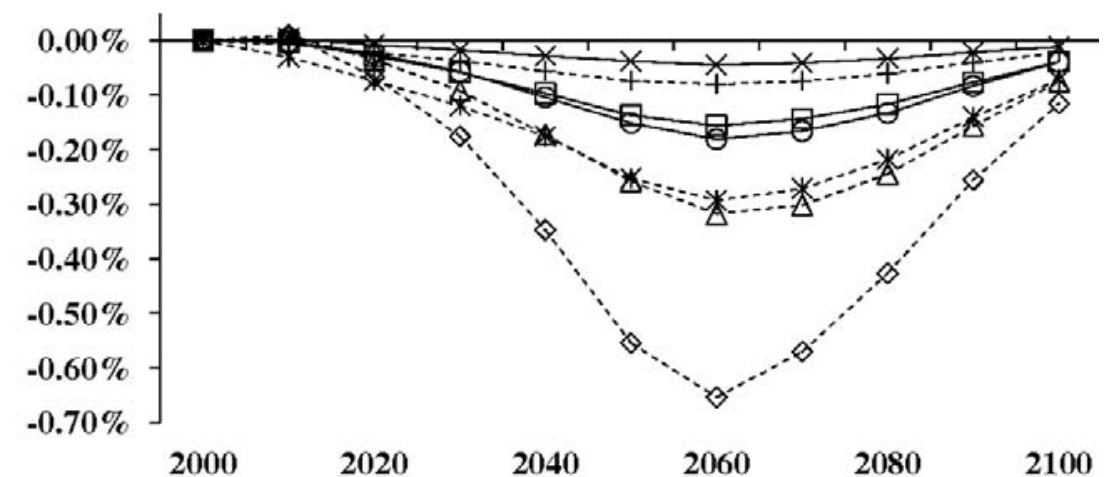

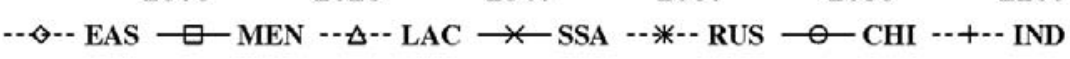

b. After shocks (\% change compared to baseline)

Figure 4: Human Capital $\left(H R_{t}^{R S}\right)$

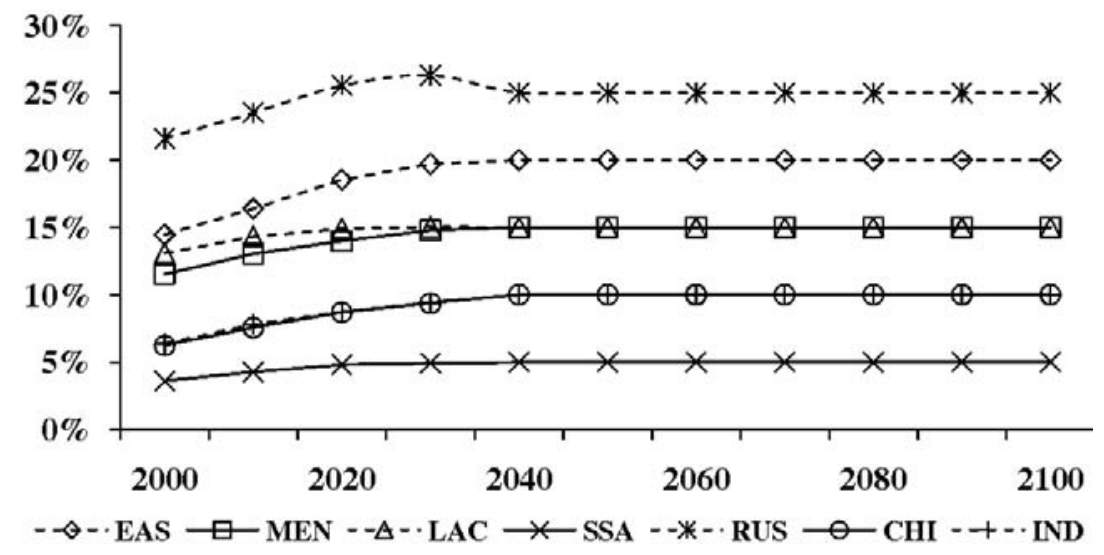

a. Baseline value

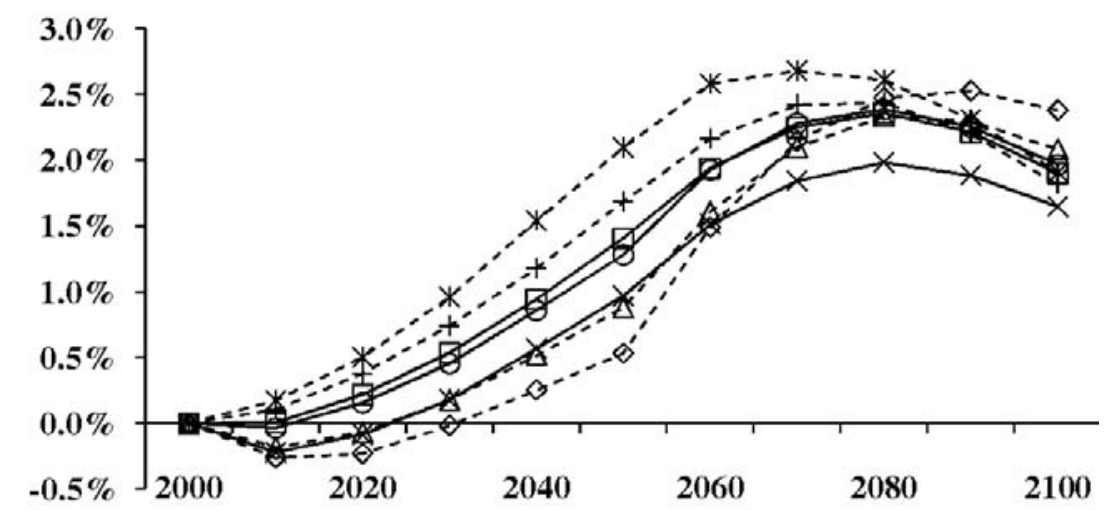

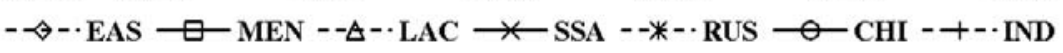

b. After shocks (\% change compared to baseline) 
Figure 5: Distance to the Technology Frontier $\left(A_{t} / A_{t}^{N A M}\right)$

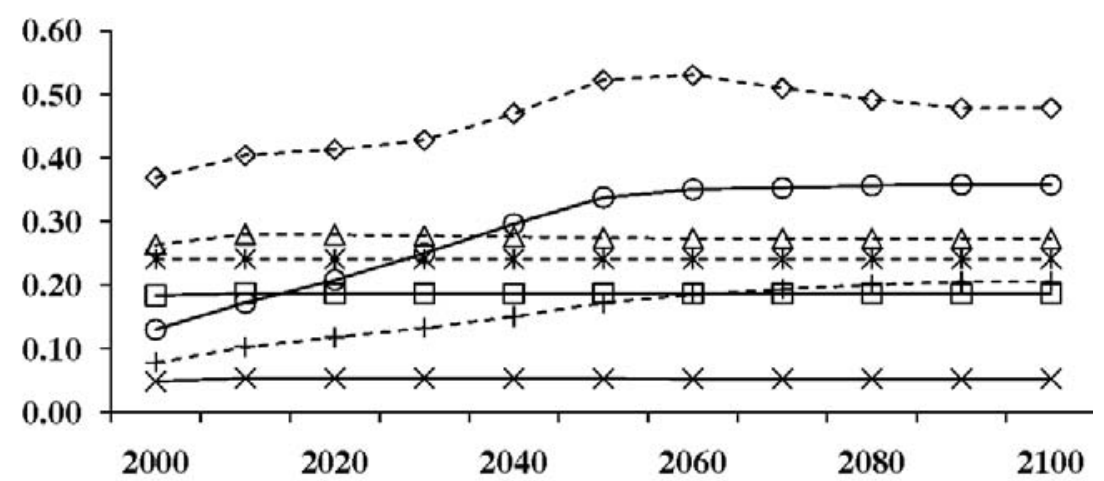

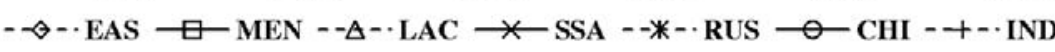

a. Baseline value

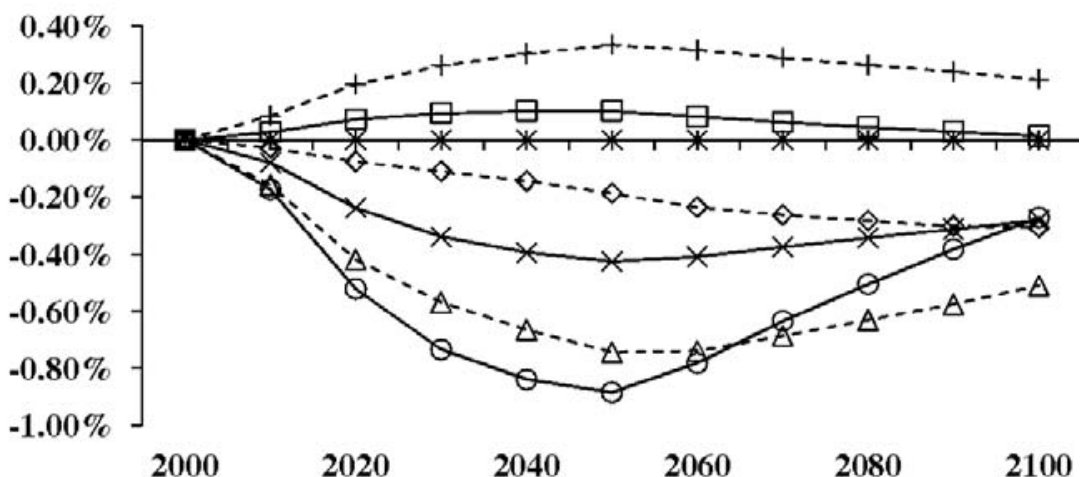
$-\diamond-\cdot$ EAS $\square-$ MEN $--A-\cdot$ LAC $\rightarrow$ SSA - - - - RUS $\multimap-$ CHI - + - IND b. After shocks (\% change compared to baseline)

Figure 6: Risk Premium $\left(\pi_{t}\right)$

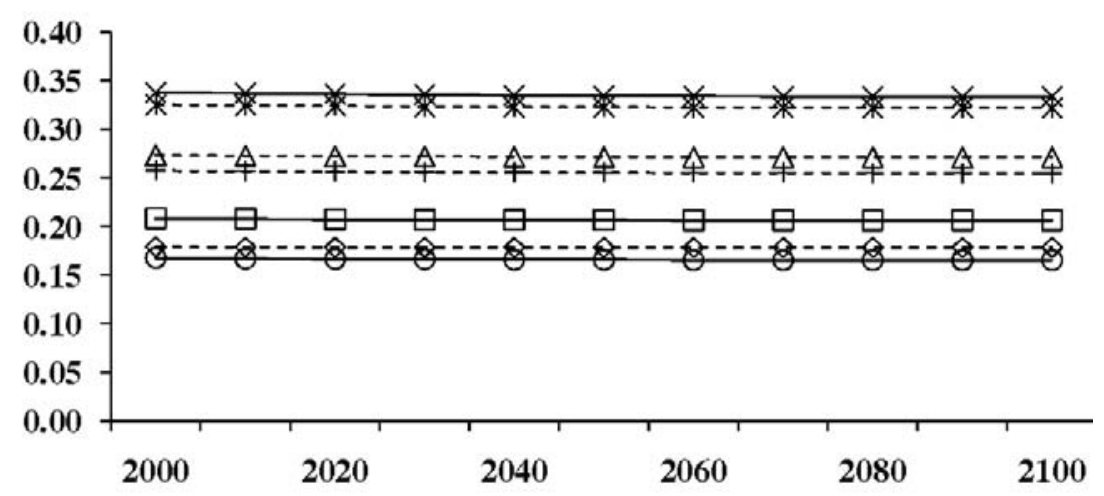

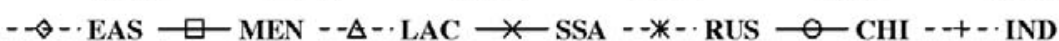

a. Baseline value

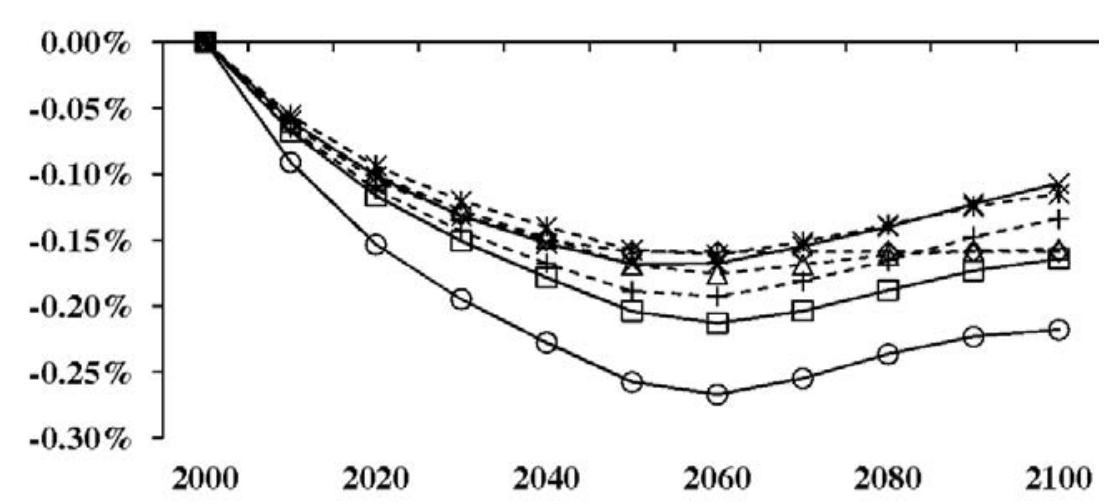

$-\diamond-\cdot$ EAS $\square-$ MEN $--\Delta-$ LAC $\rightarrow$ SSA - - *-- RUS - CHI - +-- IND

b. After shocks (\% change compared to baseline) 
Figure 7: Disentangled effects on GDP per capita
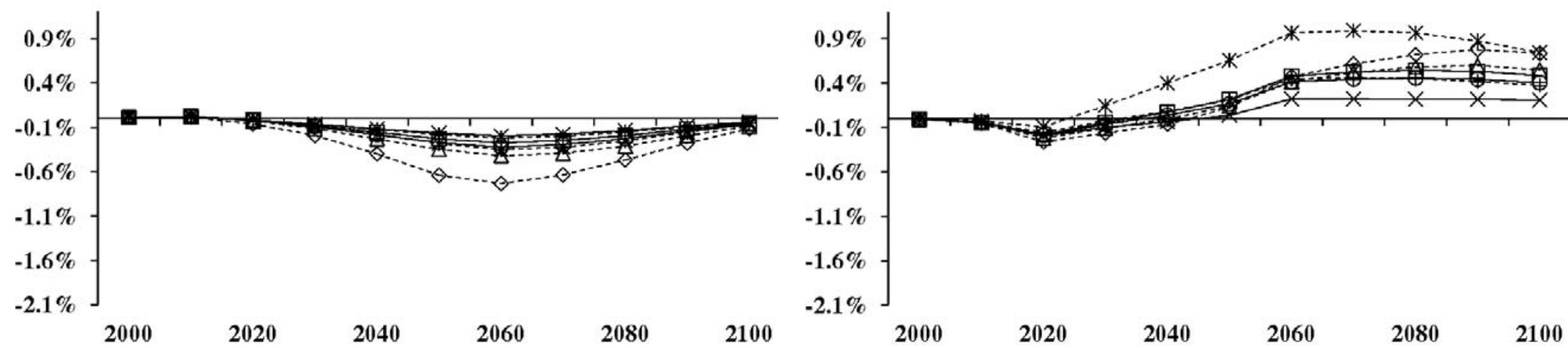

$\cdots \diamond-$ EAS $\square-$ MEN $-\Delta--$ LAC $*$ SSA -- *- RUS - - CHI --+- IND

a. Through demography $\left(m_{t}\right)$

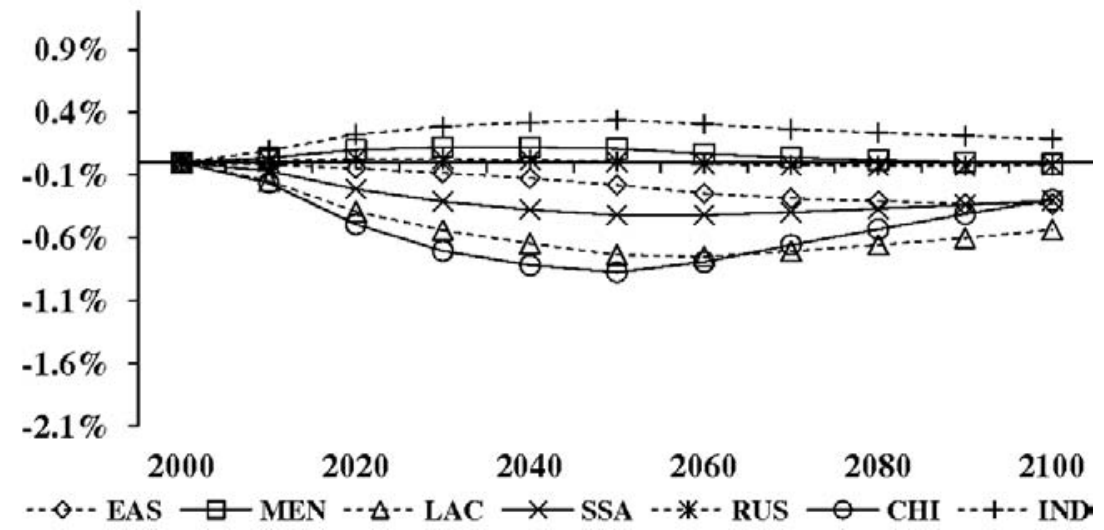

c. Through technological progress $\left(A_{t}\right)$ $\cdots \diamond-$ EAS $\square-$ MEN $\cdots \Delta \cdot-$ LAC $\rightarrow$ SSA $\cdots *-$ RUS -0 CHI $\cdots+\cdots$ IND

b. Through human capital $\left(\phi_{t}\right)$

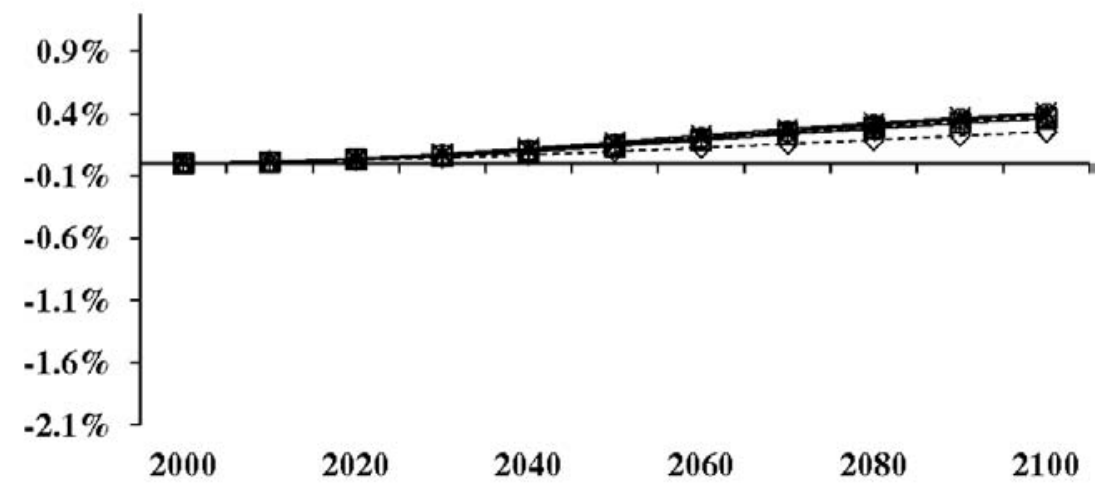

d. Through risk premium $\left(\pi_{t}\right)$ 
Figure 8: Total impacts on GDP per capita

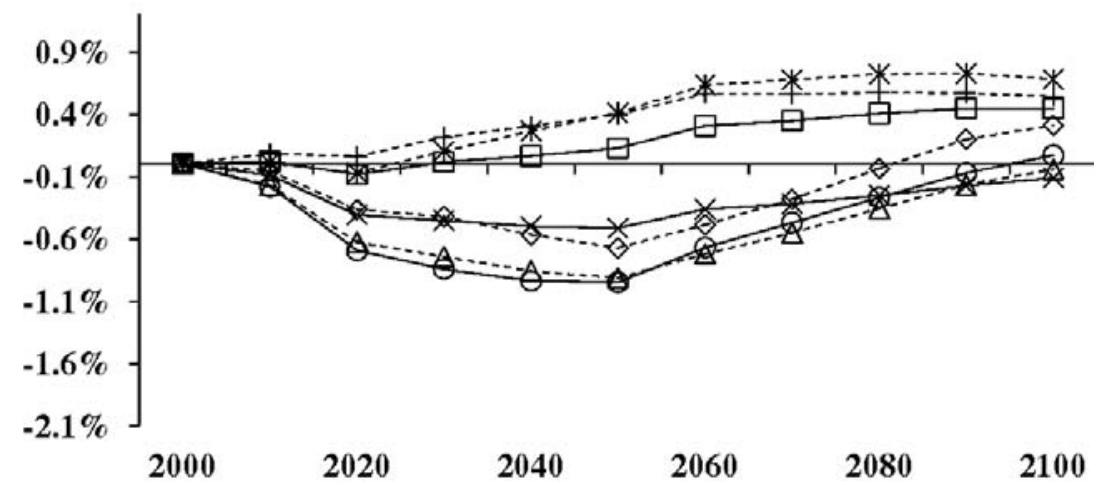

$\cdots \diamond-$ EAS $\square-$ MEN -- - LAC $\rightarrow$ SSA --*- RUS - - CHI --+- IND

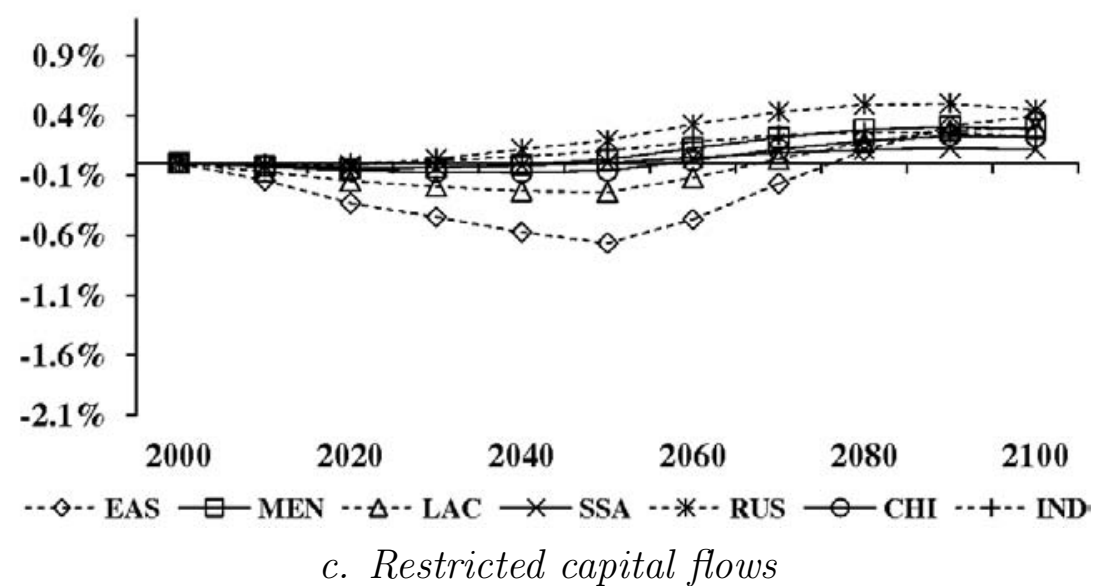

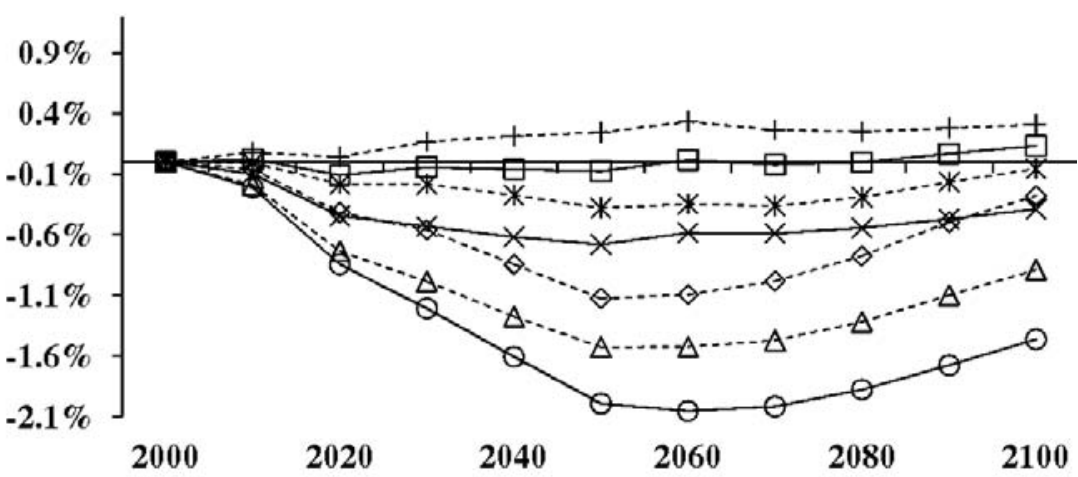

$\cdots \diamond \cdots$ EAS $\square-$ MEN $\cdots \Delta \cdot$ LAC $\rightarrow$ SSA $\cdots *-$ RUS $\multimap-$ CHI $\cdots+\cdots$ IND

b. Lack of incentive effect

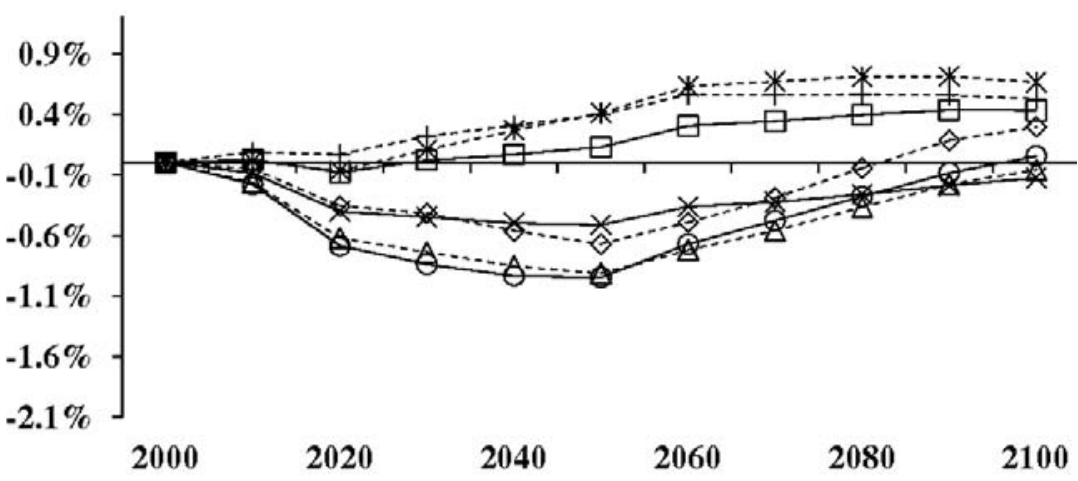

$\cdots \diamond-$ EAS $\square-$ MEN $\cdots \Delta \cdots$ LAC $\rightarrow$ SSA $\cdots *-$ RUS -0 CHI $\cdots+\cdots$ IND

d. Lower propensity to remit 
Figure 9: Total impacts on GNI per capita

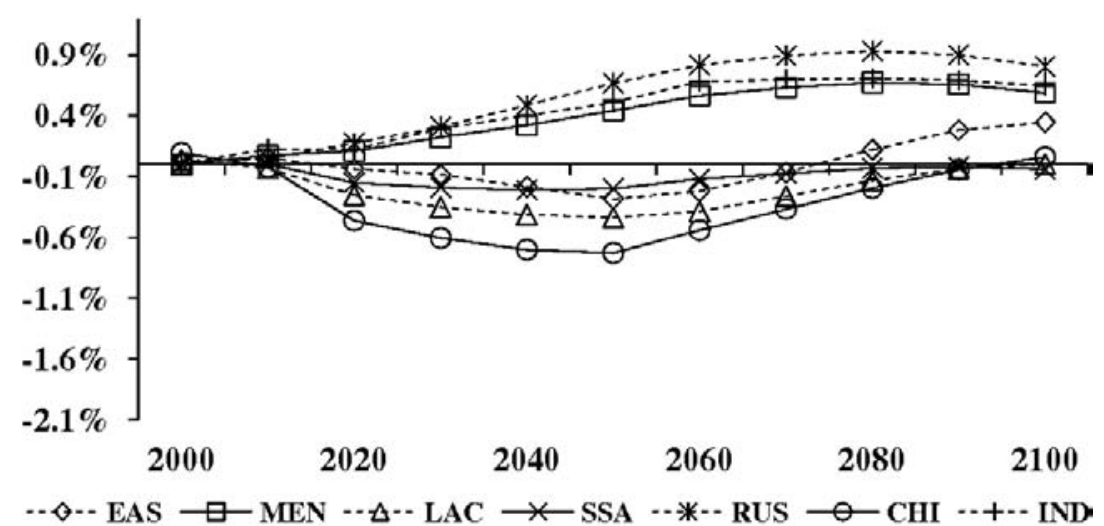

a. Calibration

$\mathbb{N}$

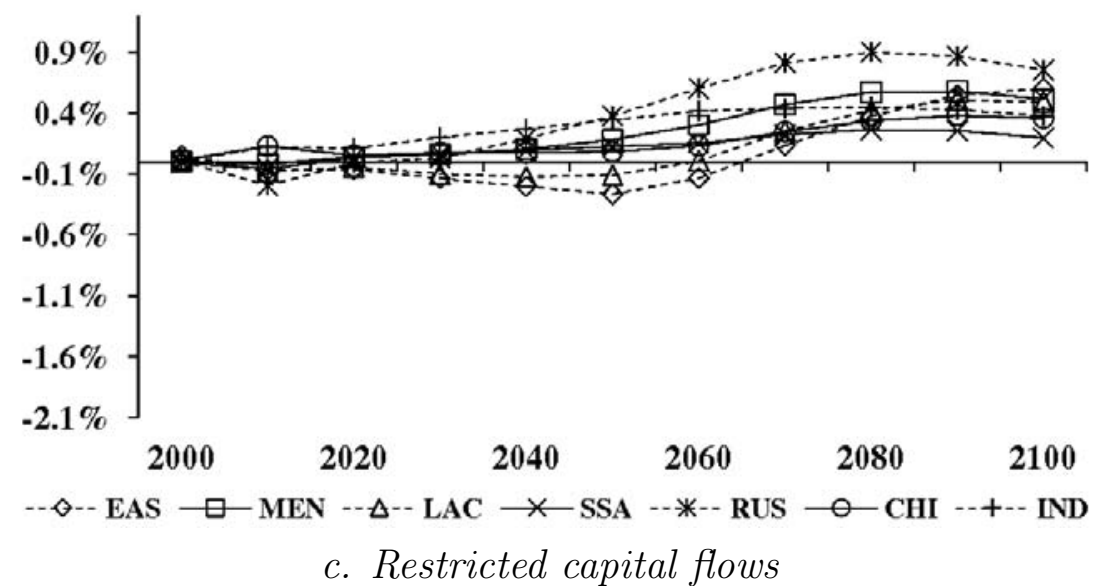

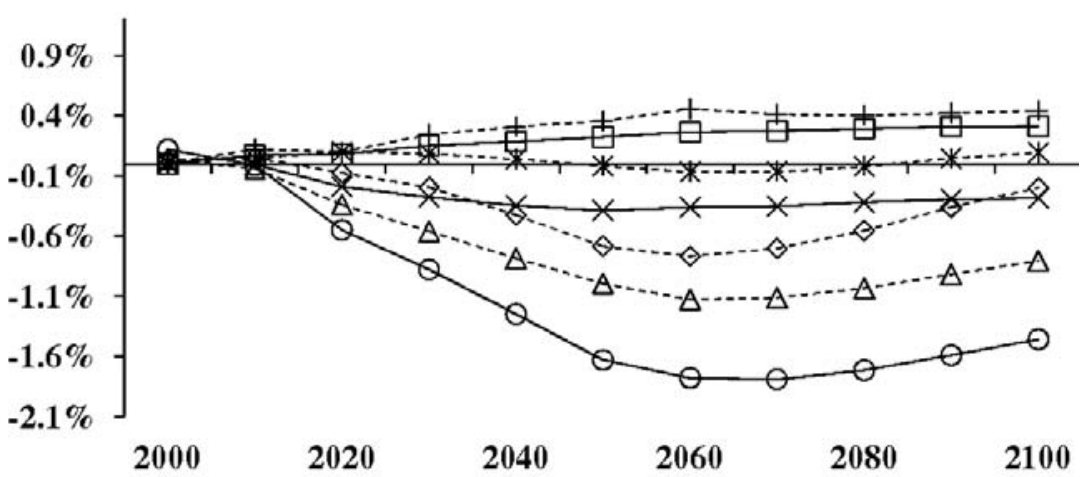

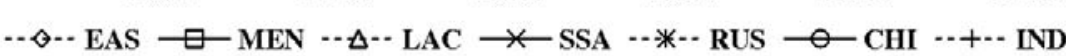

b. Lack of incentive effect

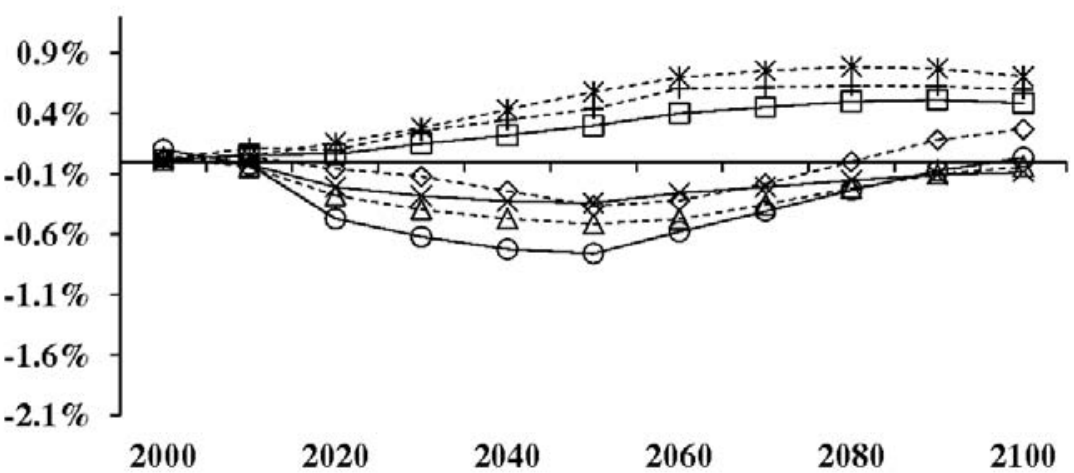

d. Lower propensity to remit 
Figure 10: Total impacts on skilled-to-less-skilled income inequality

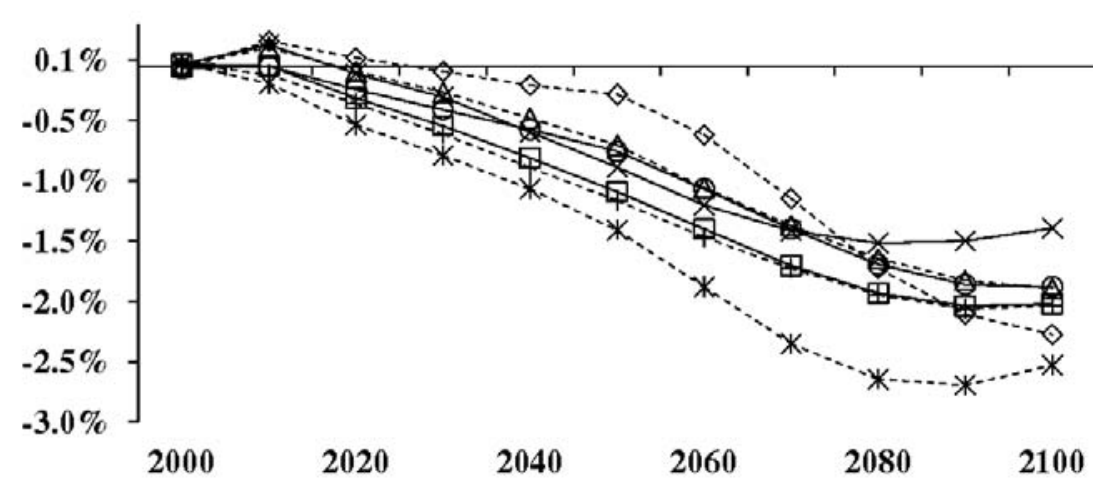

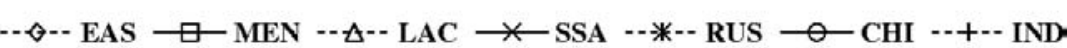

a. Calibration

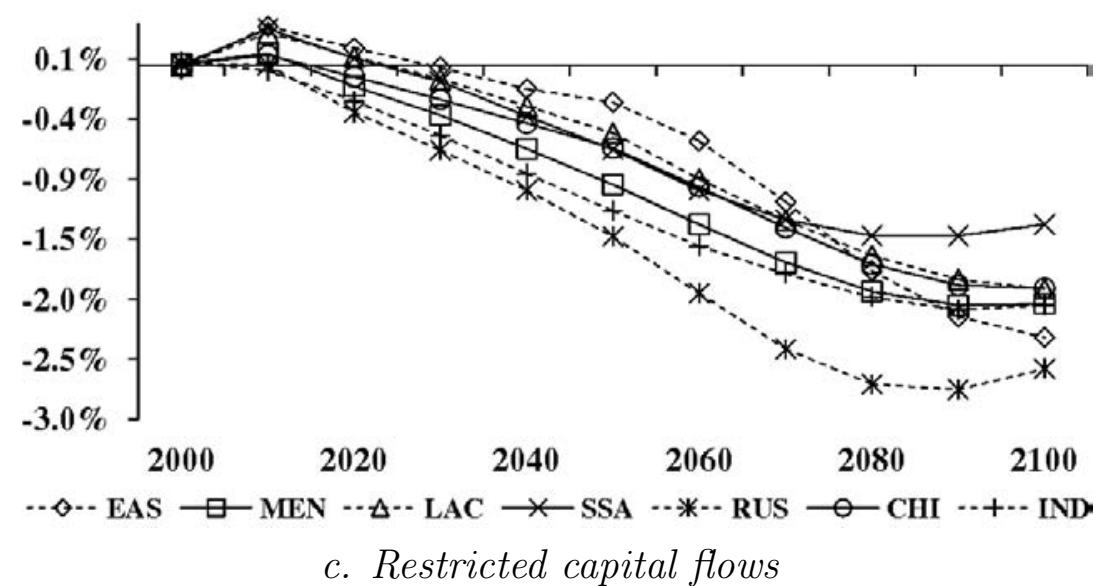

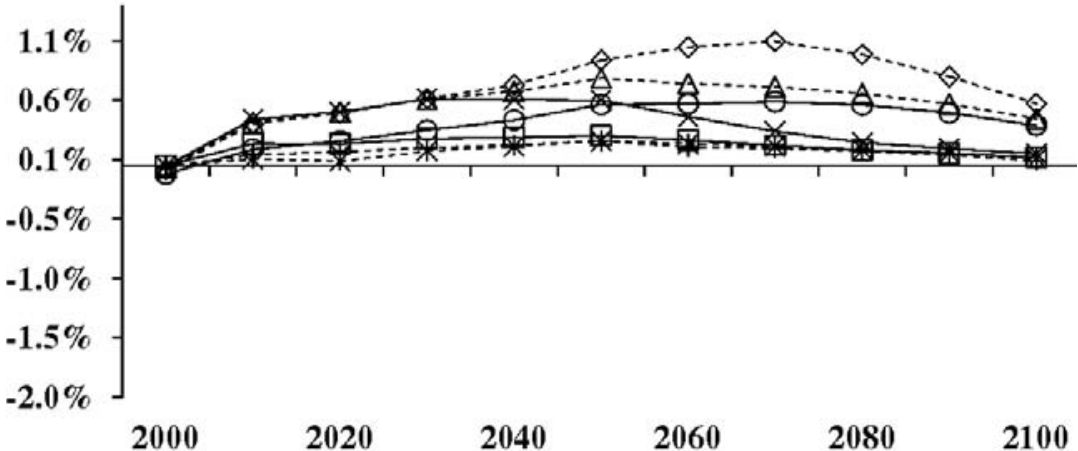

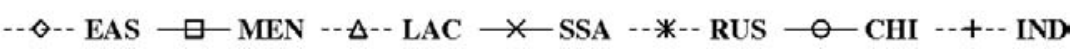
b. Lack of incentive effect

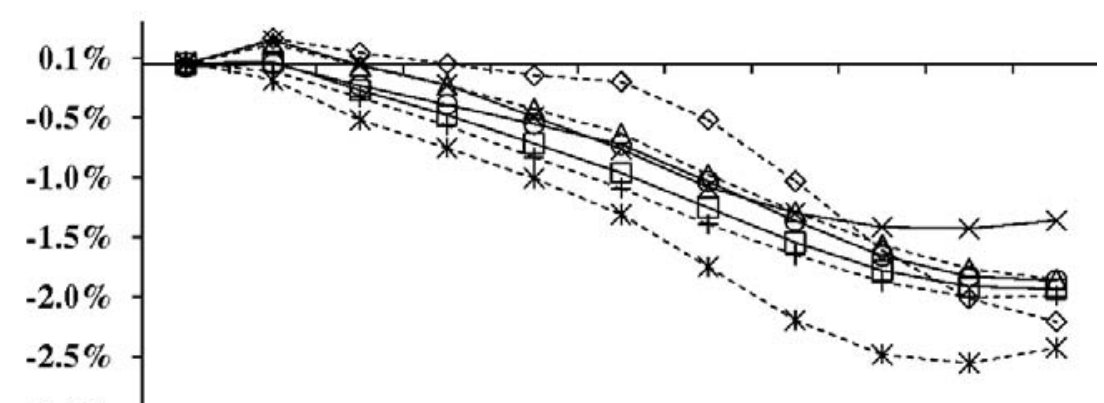
$-3.0 \%$

$\begin{array}{llllll}2000 & 2020 & 2040 & 2060 & 2080 & 2100\end{array}$

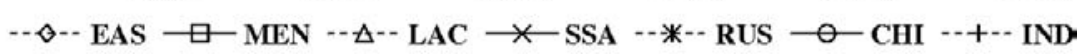

d. Lower propensity to remit 
Figure 11: Comparing alternative scenarios in 2060
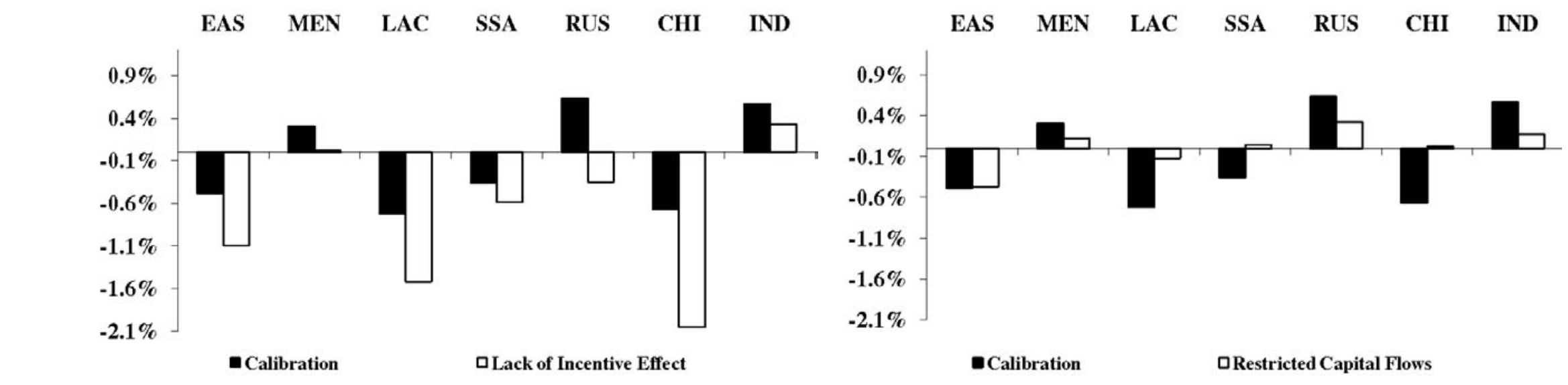

$\stackrel{\$}{\$}$

a. GDP per capita
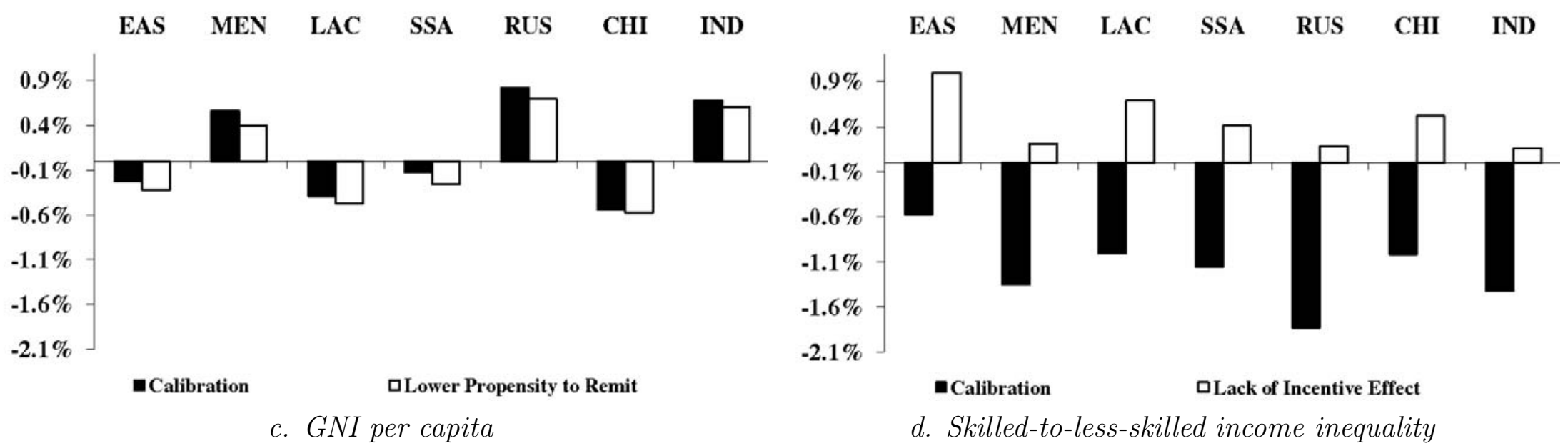
Table A.1: List of countries by region

\begin{tabular}{|c|c|c|}
\hline $\begin{array}{l}\text { Region } \\
\text { Code }\end{array}$ & $\begin{array}{l}\text { Region } \\
\text { Name }\end{array}$ & Countries \\
\hline NAM & $\begin{array}{l}\text { North } \\
\text { America }\end{array}$ & United States, and Canada. \\
\hline ADV & $\begin{array}{l}\text { Advanced } \\
\text { Countries }\end{array}$ & $\begin{array}{l}\text { Australia, Austria, Belgium, Denmark, Finland, France, Ger- } \\
\text { many, Greece, Iceland, Ireland, Italy, Luxembourg, Netherlands, } \\
\text { New Zealand, Norway, Portugal, Spain, Sweden, Switzerland, and } \\
\text { United Kingdom. }\end{array}$ \\
\hline JAP & Japan & Japan. \\
\hline$\overline{\mathrm{EAS}}$ & $\begin{array}{l}\text { Eastern } \\
\text { Europe }\end{array}$ & $\begin{array}{l}\text { Albania, Bosnia and Herzegovina, Bulgaria, Croatia, Czech Re- } \\
\text { public, Estonia, Hungary, Latvia, Lithuania, Macedonia, Poland, } \\
\text { Romania, Serbia and Montenegro, Slovakia, and Slovenia. }\end{array}$ \\
\hline MEN & $\begin{array}{l}\text { Middle } \\
\text { East and } \\
\text { North } \\
\text { Africa }\end{array}$ & $\begin{array}{l}\text { Algeria, Bahrain, Cyprus, Egypt, Iran, Iraq, Israel, Jordan, } \\
\text { Kuwait, Lebanon, Libyan Arab Jamahiriya, Malta, Morocco, Oc- } \\
\text { cupied Palestinian Territory, Oman, Qatar, Saudi Arabia, Syr- } \\
\text { ian Arab Republic, Tunisia, Turkey, United Arab Emirates, and } \\
\text { Yemen. }\end{array}$ \\
\hline $\mathrm{LAC}$ & $\begin{array}{l}\text { Latin } \\
\text { Amer- } \\
\text { ica and } \\
\text { Caribbean }\end{array}$ & $\begin{array}{l}\text { Argentina, Bahamas, Barbados, Belize, Bolivia, Brazil, Chile, } \\
\text { Colombia, Costa Rica, Cuba, Dominican Republic, Ecuador, El } \\
\text { Salvador, Guatemala, Guyana, Haiti, Honduras, Jamaica, Mexico, } \\
\text { Nicaragua, Panama, Paraguay, Peru, Saint Lucia, Saint Vincent } \\
\text { and the Grenadines, Suriname, Trinidad and Tobago, Uruguay, } \\
\text { and Venezuela. }\end{array}$ \\
\hline$\overline{\mathrm{SSA}}$ & $\begin{array}{l}\text { Sub- } \\
\text { Saharan } \\
\text { Africa }\end{array}$ & $\begin{array}{l}\text { Angola, Benin, Botswana, Burkina Faso, Burundi, Cameroon, } \\
\text { Cape Verde, Central African Republic, Chad, Comoros, Congo, } \\
\text { Congo Democratic Republic, Djibouti, Equatorial Guinea, Er- } \\
\text { itrea, Ethiopia, Ivory Coast, Gabon, Gambia, Ghana, Guinea, } \\
\text { Guinea-Bissau, Kenya, Lesotho, Liberia, Madagascar, Malawi, } \\
\text { Mali, Mauritania, Mauritius, Mozambique, Namibia, Niger, Nige- } \\
\text { ria, Rwanda, Sao Tome and Principe, Senegal, Sierra Leone, So- } \\
\text { malia, South Africa, Sudan, Swaziland, Tanzania, Togo, Uganda, } \\
\text { Zambia, and Zimbabwe. }\end{array}$ \\
\hline RUS & $\begin{array}{l}\text { Former } \\
\text { Soviet } \\
\text { Union }\end{array}$ & $\begin{array}{l}\text { Armenia, Azerbaijan, Belarus, Georgia, Kazakhstan, Kyrgyzstan, } \\
\text { Moldova, Russian Federation, Tajikistan, Turkmenistan, Ukraine, } \\
\text { and Uzbekistan. }\end{array}$ \\
\hline $\mathrm{CHI}$ & $\begin{array}{l}\text { Chinese } \\
\text { World }\end{array}$ & $\begin{array}{l}\text { Brunei, Burma, Cambodia, China, East Timor, Hong Kong, Ko- } \\
\text { rea, Lao People's Democratic Republic, Macau, Mongolia, Philip- } \\
\text { pines, Singapore, Thailand, and Vietnam. }\end{array}$ \\
\hline IND & $\begin{array}{l}\text { Indian } \\
\text { World } \\
\text { and } \\
\text { Pacific } \\
\text { Islands }\end{array}$ & $\begin{array}{l}\text { Afghanistan, Bangladesh, Bhutan, Federated States of Microne- } \\
\text { sia, Fiji, India, Indonesia, Malaysia, Maldives, Nepal, Pakistan, } \\
\text { Papua New Guinea, Samoa, Solomon Islands, Sri Lanka, Tonga, } \\
\text { and Vanuatu. }\end{array}$ \\
\hline
\end{tabular}

